ISSN 2287-6200

\title{
Capital Market Openness and Output Volatility
}

Kwang-Myoung Hwang Donghyun Park

Kwanho Shin

BOK Working Paper No. 2013-14

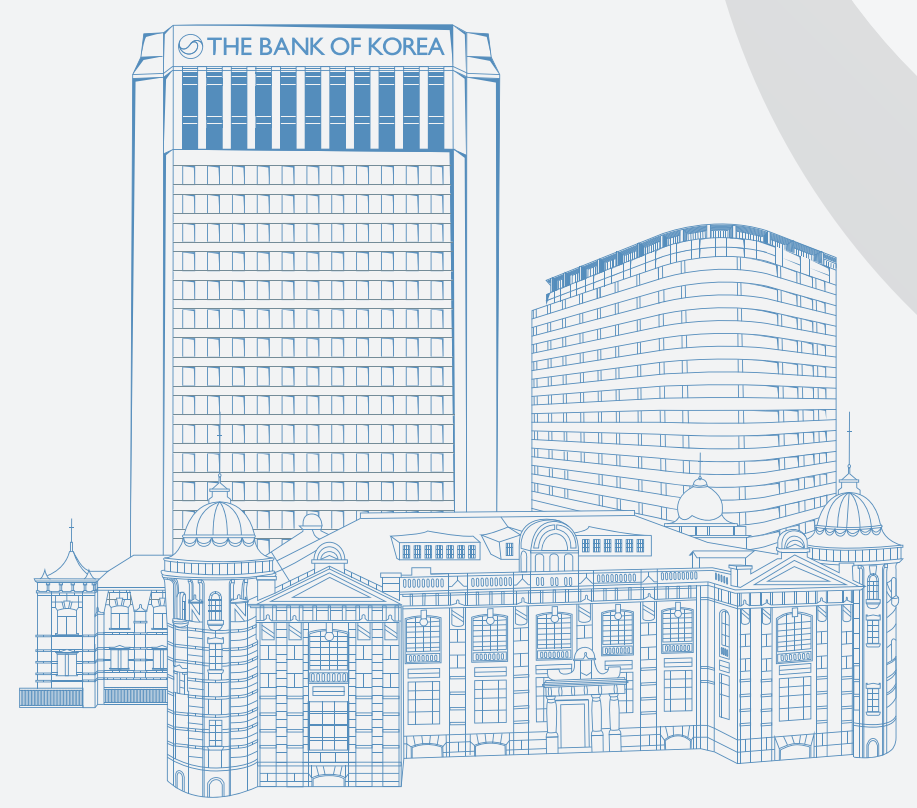

THE BANK OF KOREA 
Economic Research Institute

The Bank of Korea

Publisher

\section{Choongsoo Kim}

(Governor of the Bank of Korea)

Editor

\section{Woon Gyu Choi}

(Director General of the Institute)
Requests for copies of publications, or for addition/changes to the mailing list, should be sent to:

Economic Research Institute

The Bank of Korea

39 Namdaemunno Jung-Gu

Seoul, 110-794, Korea

E-mail: eso@bok.or.kr

Fax: 82-2-759-5410

This publication available on the $\mathrm{BOK}$

Economic Research Institute website

(http://imer.bok.or.kr)

(C) The Bank of Korea, 2013

All rights reserved.

Reproduction for educational and non-commercial purposes is permitted provided that the source is acknowledged.
The views expressed in this paper do not necessarily
reflect those of the Bank of Korea or the Economic Research Institute.
BOK Working Paper is occasionally published by the Economic Research Institute, the Bank of Korea. This is circulated in order to stimulate discussion and comments. Articles include research achievement by the staff and visiting scholars, and selected works sponsored by the Institute. 


\title{
Capital Market Openness and Output Volatility
}

\author{
Kwang-Myoung Hwang* \\ Donghyun Park** \\ Kwanho Shin***
}

The views expressed herein are those of the authors and do not necessarily reflect the official views of the Bank of Korea or ADB. When reporting or citing it, the authors' names should always be stated explicitly.

* Senior Economist, Macroeconomics Team, Economic Research Institute, The Bank of Korea, 39, Namdaemunno, Jung-gu, Seoul, KOREA 100-794, Email: hwangkm@bok.or.kr, [Tel] 82-2-759-5468, [Fax] 82-2-759-5420

** Principal Economist, Macroeconomics and Finance Research Division, Economics and Research Department, Asian Development Bank, 6 ADB Avenue, Mandaluyong City, Metro Manila, PHILIPPINES 1550. [E-mail] dpark@adb.org, [Tel] 63-2-6325825, [Fax] 63-2-6362342

*** Professor, Department of Economics, Korea University, 5-1 Anam-Dong, Sungbuk-Ku, Seoul, KOREA 136-701. [E-mail] khshin@korea.ac.kr, [Tel] 82-2-32902220, [Fax] 82-2-3290-2719

Financial support from the Bank of Korea is gratefully acknowledged. This paper has been presented at the Bank of Korea and Asian Development Bank. We like to give special thanks to Woon Gyu Choi, Seung-Cheol Jeon, Hyun Jeong Kim, and other participants in the seminars for their valuable comments. 


\section{Contents}

I. Introduction ................................................................. 1

II. Data

III. Empirical results

IV. Implication for Asian countries ................................... 28

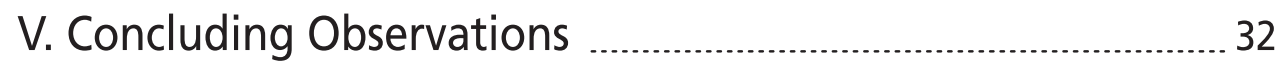

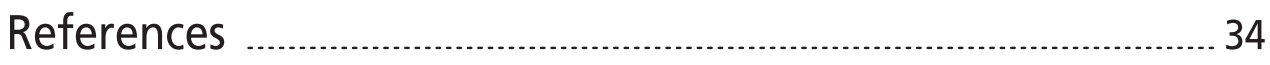




\section{Capital Market Openness and Output Volatility}

At a conceptual level, opening of capital markets entails a number of benefits and costs. One major cost of financial openness is output volatility. In this paper, using data from 21 advanced and 81 developing countries during 19712010, we empirically examine the impact of capital market openness on output volatility. We find that opening of capital markets increases the output volatility of developing countries. Furthermore, we find that the main channel through which capital market openness increases volatility is currency and external-debt crisis. Finally we find that, while Asian countries are less likely to experience a crisis, they become even more unstable than other developing countries once a crisis occurs. Our evidence strengthens the case for caution in developing countries' opening up of their capital markets.

Keywords: Capital market openness, Financial openness, Financial liberalization, Output volatility, Financial crisis

JEL Classification: F32, F21, F43, F41, G01 


\section{Introduction}

Trade openness is widely considered to be beneficial for economic performance. Trade enables countries to specialize in their areas of comparative advantage and thus allows for international division of labor. From a dynamic perspective, trade exposes firms and industries to greater competition and thus forces them to become more productive and innovative. The notion that trade and trade openness are on the whole beneficial, is one of the few areas of widespread agreement among economists. ${ }^{1)}$ Over the past few decades, the most successful exporters have been the fastest-growing developing countries. In particular, a group of East Asian countries achieved the East Asian miracle on the back of export-oriented industrialization. More recently, China and to a lesser extent India leveraged trade openness and integration into the world economy to fast-track their growth.

In striking contrast, there is a heated and passionate controversy surrounding the benefits of financial openness. The debate is especially emotional in developing countries where opening of capital markets is often viewed as harmful and externally imposed by the IMF and advanced countries. While financial openness may accelerate economic growth, it may also increase output volatility (Prasad et al., 2007; Levchenko et al., 2009; and Popov, 2011). Developing countries often have investment needs which exceed their domestic savings and thus rely on foreign savings to bridge the gap. Foreign direct investment has been a catalyst of growth in many developing countries ${ }^{2}$ but other forms of foreign capital can contribute to growth as well. On the other hand, large and volatile inflows of foreign capital into financially underdeveloped countries have wrought havoc on financial systems and real economies. Some examples include the Asian financial crisis of 1997-1998, the Turkish financial crisis of 2000-2001 and the Argentine debt crisis of 2001-2002.

More broadly, at a conceptual level, capital market openness entails a number of benefits as well as costs. On the plus side, financial openness can contribute to

1) While there is a fairly strong consensus in the literature that trade openness is welfare enhancing, there are concerns that trade openness may amplify output volatility. See, among others, Kose et al. (2006). However, we believe that overall the benefits from trade openness exceed any cost stemming from heightened volatility.

2) Singapore is a classical example. See, for example, Feridun and Sissoko (2011), Jayawickrama and Thangavelu (2010), and Anwar (2008). 
economic growth by fostering capital accumulation and technology spillovers. Such potential benefits are especially significant for developing countries where the marginal returns to capital tend to be high and the technology level tends to be low. Financial openness also enables countries to smooth their consumption over time and share risks with other countries. Additional, collateral gains include financial sector development, improvement of institutions and governance, and macroeconomic policy. On the minus side, financial openness limits monetary policy independence and thus the scope for using monetary policy for domestic objectives such as countercyclical stabilization. Another major potential cost is heightened economic volatility. More specifically, financial openness can precipitate volatile capital flows and volatile interest rates. Furthermore, an additional potential cost of openness is heightened vulnerability to crises and external shocks.

In this paper, we do not purport to examine all the benefits and costs of financial openness. Instead, we limit our analysis to one specific cost, namely output volatility. In the theoretical and empirical literature, there is no consensus on whether financial openness increases output volatility. In theory, if opening of capital markets allows developing countries to diversify away from natural-resource dependent production structures, then output volatility can be reduced. Loayza et al. (2007) argue that closing the economy off from financial flows may increase the likelihood of policy-induced distortions that eventually result in large domestic shocks. Conversely, in financially open economies, the fear of capital outflows imposes a firm discipline against unsound policies. However, there are also counterarguments. For an example, while enhanced risk sharing allows countries to specialize, this may render them more vulnerable to industry-specific shocks, leading to higher output volatility (Kose et al., 2009).

The empirical evidence is also mixed. For a sample of 138 countries during 19501988, Razin and Rose (1994) find no link between financial openness and the volatility of output. Buch et al. (2005), using data for 25 advanced countries, find no consistent empirical relationship between financial openness and output volatility. On the other hand, Bekaert, Harvey, and Lundblad (2006) find that equity market liberalization lowers output volatility.

Our two main questions are (1) Does capital market openness increase output volatility?, and (2) if so, what are channels through which financial openness increases output volatility? Our empirical analysis of the relationship between capital 
market openness and output volatility is based on data from 21 advanced and 81 developing countries. We explicitly examine the main channels through which financial openness can cause volatility. Our analysis yields a number of interesting findings. Above all, we find that output is more volatile in developing countries, and that financial openness increases the volatility of output in developing countries. We then investigate the channels through which financial openness influences output volatility in developing countries. The three main channels identified in the literature are (1) volatile capital flows, (2) volatile real interest rates, and (3) financial and economic crises. Our findings suggest that the main channel through which financial openness increases output volatility is crisis, more specifically currency and external debt crises. Neither volatile capital flows nor volatile interest rates have a significant effect on output volatility.

The rest of the paper is organized as follows. Section 2 briefly explains the data sources and construction of variables. Section 3 reports and discusses our main empirical findings. Section 4 spells out the implications of our analysis for Asian countries, and section 5 concludes the paper with some final observations.

\section{Data}

In this section, we describe the data used for our empirical analysis, and explain the construction of our variables. Our sample period is 1971-2010, which encompasses a time frame during which advanced economies fully embraced opening of capital markets and many developing countries also became financially more open. Reinhart \& Rogoff (2009) identified six types of economic and financial crises, which are banking, currency, domestic debt, external debt, stock market, and inflation crises. We use only currency and external debt crises since these are most likely to result from the opening of financial markets. The Asian financial crisis of 19971998 is the classical example of a currency crisis stemming from financial openness while the Latin American debt crisis of the 1980s epitomizes an external debt crisis rooted in capital market openness.

Our sample of countries consists of 21 advanced and 81 developing countries. 
Our classification of advanced versus developing countries follows International Financial Statistics 1996 [IFS]. There are a few developing countries whose status changed to advanced countries after $1996^{3)}$. Nevertheless, since our data go back to the 1970 s, we ignore these changes. Countries which were classified as developing countries in 1996 are classified as such even if they became advanced countries after 1996. We also exclude countries with population less than one million to avoid outlier problems.

Our key variable of interest is financial openness. Following most of the literature, we experiment with two alternative measures of financial openness, which are de jure and de facto measures. Our de jure measure follows Chinn and Ito (2006), which is based on IMF's Annual Report on Exchange Arrangement and Exchange Restrictions. Our de facto measure follows 'External Wealth of Nations Mark II database' of Lane and Milesi-Ferretti (2007) in order to obtain more time series. It measures stocks of foreign assets and liabilities rather than flows. This measure may be subject to measurement errors. The data for our other variables are drawn from World Bank's World Development Indicators [WDI].

$<$ Table 1> summarizes our data. We divide the whole sample into four decades - 1970s, 1980s, 1990s, and 2000s. According to both de jure and de facto measures, financial openness has been increasing in both developed and developing countries. Capital flow volatility, measured as the standard deviation of the ratio of net capital inflow to GDP, has also been increasing. Real interest rate volatility, measured as the standard deviation of real interest rates, peaked in the 1990s but fell back in the 2000s. Trade openness, measured as the ratio of export plus import to GDP, has been increasing. The frequency of crisis peaked in the 1980s but then steadily decreased.

3) Some examples are Hong Kong, Israel, Singapore, and South Korea. 


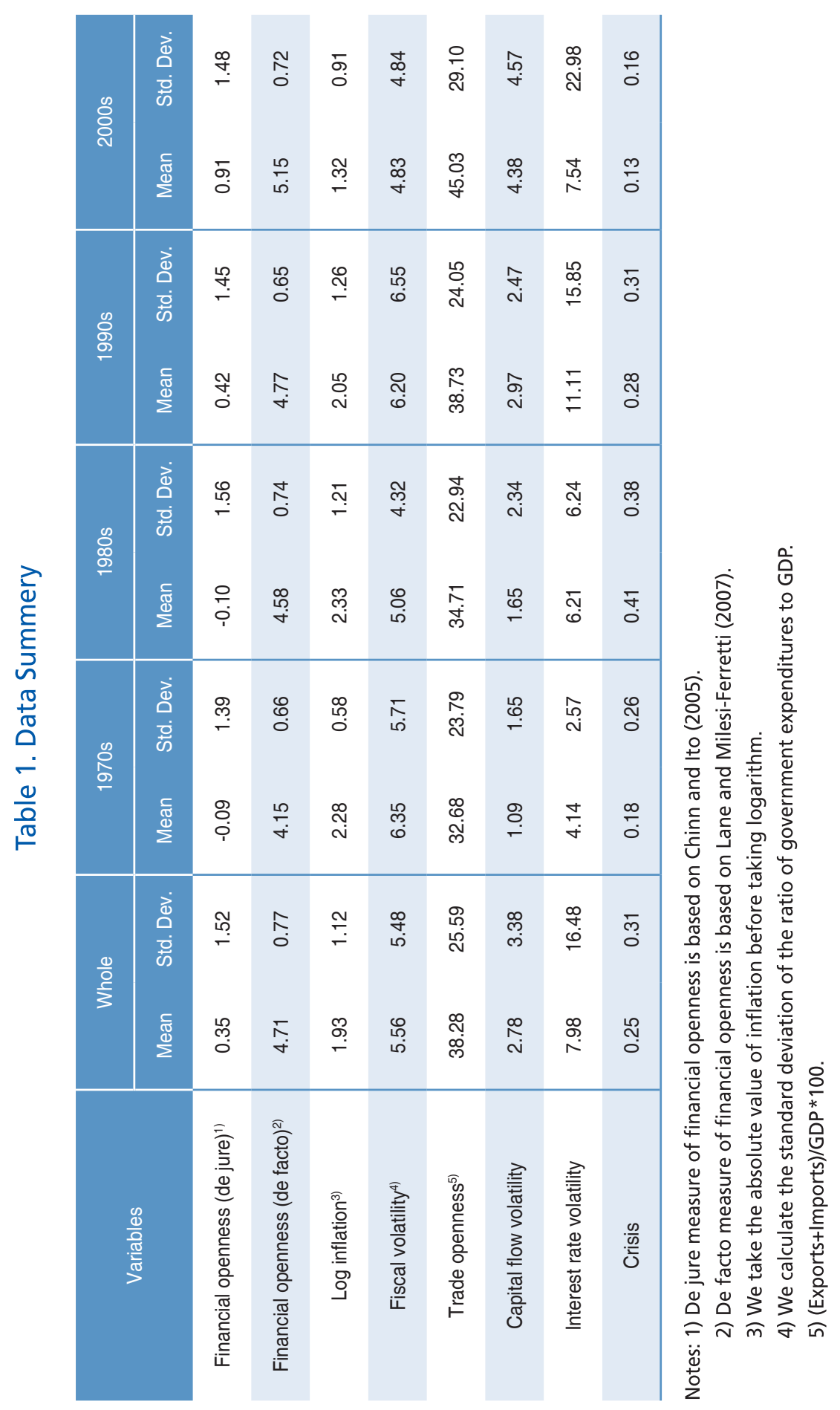




\section{Empirical results}

In this section, we report and discuss the main findings that emerge from our empirical analysis, which consists of two parts - (1) effect of capital market openness on output volatility and (2) main channels through which financial openness increases output volatility.

\section{Does capital market openness increase output volatility?}

$<$ Table 2> reports the growth and volatility of GDP of our sample countries during the 1970s, 1980s, 1990s, and 2000s. Two different measures of volatility are used, which are standard deviation and skewness of annual real GDP growth rates. Countries with high standard deviation and low skewness of GDP growth rates may be considered as highly volatile countries. Lower skewness means the distribution of GDP growth rates has a larger fat tail on the left side, which implies that the probability of extremely low GDP growth rates becomes greater. Therefore, in evaluating output volatility, we give greater weight to negative shocks. We classify countries in terms of financial openness. We define a country as financially open if the Chinn-Ito index - de jure openness measure - is greater than zero, or if the ratio of foreign assets plus liabilities to GDP - de facto openness measure - is greater than the average value, which is $80 \%$.

We find that developing countries grew faster than advanced economies, which supports the notion of income convergence over time. In general, however, output volatility is higher in developing countries than in advanced economies. For both de jure and de facto measures, standard deviation of output in developing countries with open financial markets is higher than in developing countries with closed financial markets. This provides a rough indication that financial openness increases output volatility in developing countries. There is no such strong evidence for skewness of output but, in developing countries with open financial markets, output skewness peaked in the 1980 s when the frequency of crises also peaked.

However, we could not compare output volatility in financially open versus financially closed advanced countries because all advanced economies became financially open by the 1990s. Other than that, our results are consistent across different measures of volatility and financial openness. 


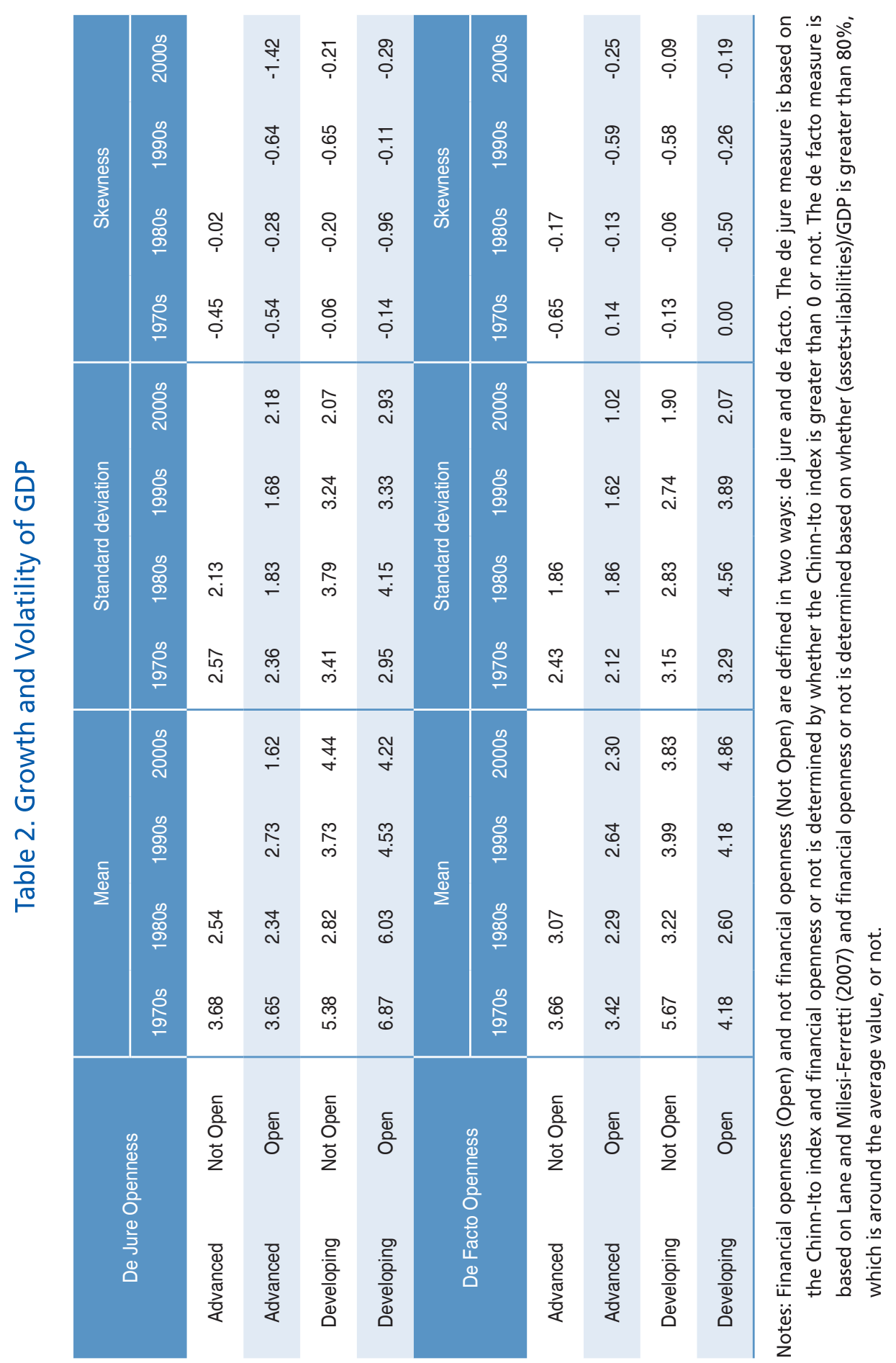


In order to investigate more rigorously the effect of financial openness on the volatility of output, we set up an empirical model, and perform country panel analyses. Our basic model is following:

$$
Y_{i, t}=\alpha+\beta \cdot \text { finopen }_{i, t}+\theta \cdot X_{i, t}+\tau_{t}+\mu_{i}+\epsilon_{i, t}
$$

where $i$ stands for a country and $t$ stands for a time.

Our dependent variable $Y_{i, t}$ is the standard deviation or skewness of real GDP growth rates for each decade - 1970s, 1980s, 1990s, and 2000s. The explanatory variables include finopen $_{i, t}$, a financial openness measure, and other control variables, $X_{i, t}$. We also add both unobservable country and time specific fixed effects. Throughout this paper, our estimation is based on four-decade panel regressions, so all explanatory variables are decade averages.

We adopt two financial openness measures: (1) de jure financial openness, which is calculated as the decade average of the Chinn-Ito index, and (2) de facto financial openness, which is calculated as the logarithm of the decade average of the ratio of foreign assets plus liabilities to GDP. Following Meller (2008), we additionally include three control variables - two policy quality variables, based on the Great Moderation literature, and trade openness. To capture monetary policy, we use the logarithm of absolute value of inflation rates (Bekaert et al., 2006; Barrell and Gottschalk, 2004; and Kose et al., 2003), and to measure fiscal policy volatility, we use the standard deviation of the ratio of government expenditures to GDP (Buch et al., 2005; Kose et al., 2003; and Spatafora and Sommer, 2007).4) Trade openness is measured as the ratio of exports plus imports to GDP. Giovanni and Levchenko (2006) find that more trade openness leads to more output volatility by increasing specialization and thus vulnerability to industry-specific shocks. $<$ Table $3>$ reports the basic results of our empirical analysis of the relationship between financial openness and output volatility.

4) There is significant scope for endogeneity between the two policy variables and output volatility since one objective of fiscal and monetary policy is to reduce output volatility. However, reassuringly, the results for the baseline regressions are similar to the regressions which include the policy variables. This suggests that our main results may not be subject to the endogeneity of the policy variables. 


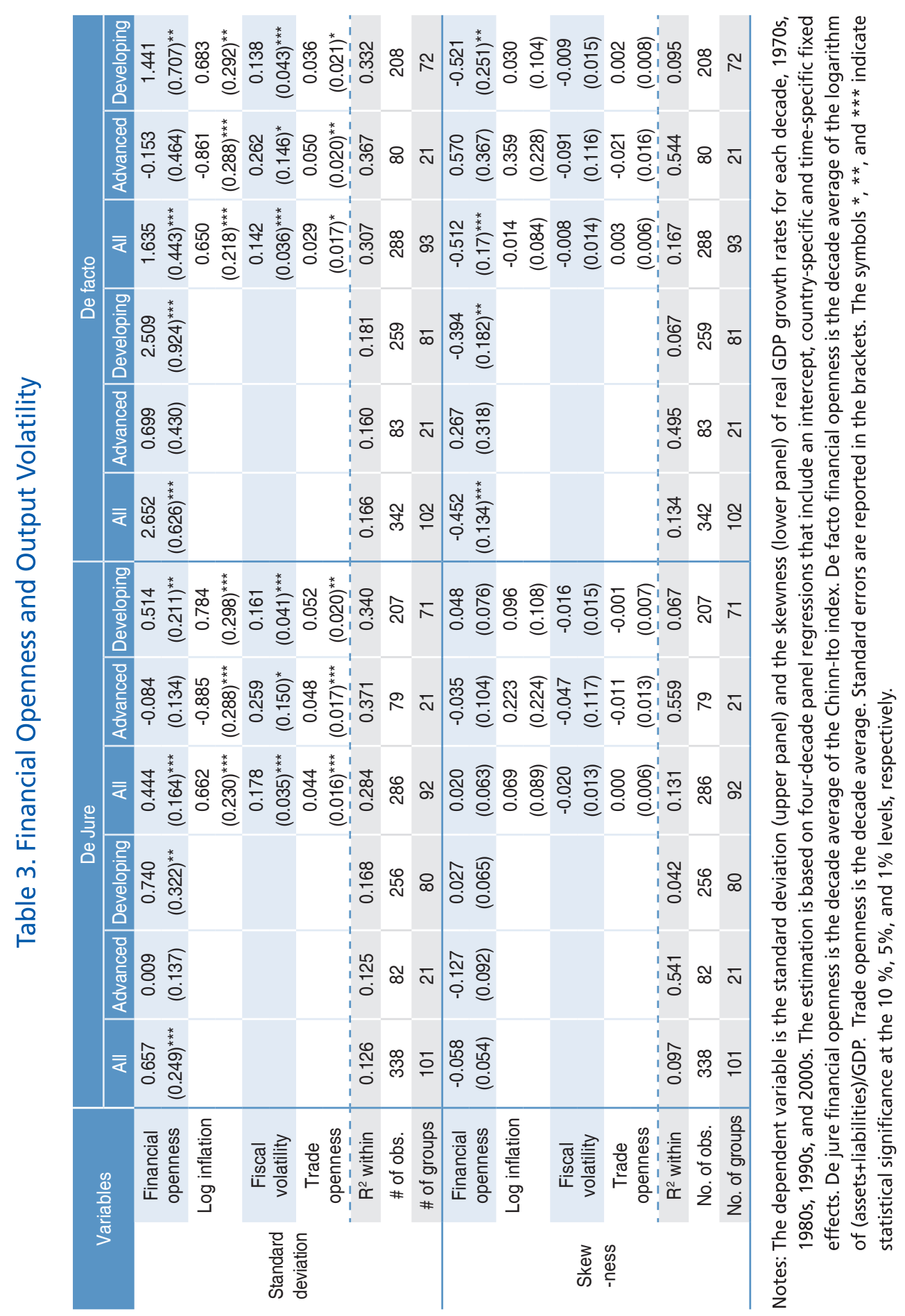


For our baseline regressions, we use only de jure or de facto openness measure as the explanatory variable and do not include the control variables. According to both de jure and de facto measures, financial openness increases the standard deviation of output. This is true for the entire sample and for developing countries, but not for advanced economies. Our finding is intuitively plausible since opening of capital markets is more likely to be destabilizing for countries with underdeveloped financial systems. For the de facto measure, we find that financial openness aggravates negative skewness of GDP growth rates. To sum up, we uncover fairly strong evidence of a significant correlation between financial openness and output volatility in developing countries.

When we add the three control variables as additional explanatory variables, all our main findings are preserved. Furthermore, all three control variables are highly significant when we use standard deviation of GDP growth rates as the dependent variable. Countries with higher inflation experience higher output volatility, as do countries with more volatile government expenditures. Finally, we find that higher output volatility is also associated with greater trade openness, in line with our conjectures about greater specialization amplifying vulnerability to industry-specific shocks.

The estimated coefficients suggest that an increase in de facto openness measure by one standard deviation - i.e. $77 \%$ increase in the ratio of foreign assets plus liabilities to GDP - increases the standard deviation of GDP in developing countries by 1.1 and reduces skewness by 0.4 . One standard deviation increase - i.e. 1.52 points - in de jure openness measure increases standard deviation of GDP in developing countries by $0.8^{5}$. Furthermore, on average, in developing countries one standard deviation increase in log absolute inflation increases standard deviation of GDP by 0.8 , and one standard deviation increase in fiscal volatility increases output volatility by $0.8^{6}$. Finally, one standard deviation increase in trade openness measure - i.e. $25.6 \%$ points - increases standard deviation of output by 1.1 .

5) The impact of de jure openness measure on skweness is not statistically significant and hence not reported.

6) We take the average of the coefficients estimated when de jure and de facto measures are used as financial openness. 


\section{$11 \quad$ BOK Working Paper No.2013-14 (2013.5)}

\section{What are the channels through which financial openness increases out- put volatility?}

The next logical question to ask is why financially open developing countries experience greater output volatility. The literature identifies three potential channels for how financial openness can cause higher output volatility. The first has to do with volatile capital flows. The underlying idea is that large and frequent capital flows can lead to asset price booms and busts ${ }^{7}$. The second stems from volatile real interest rates associated with reduced monetary policy independence in financially open economies. Frequent and large swings in real interest rates in emerging economies can magnify business cycles (Neumeyer and Perri, 2005). More generally, interest rate shocks induce a wealth effect, an inter-temporal consumption-substitution effect, and redistribution of savings, inducing business cycle fluctuations (Mendoza, 1991). Finally, financially open economies may be more prone to crisis since abrupt reversals of capital inflows may precipitate a financial crisis - e.g. Asian financial crisis. $^{8)}$

Now we modify the model to explicitly include the three channels:

$$
Y_{i, t}=\alpha+\beta \cdot \text { finopen }_{i, t}+\gamma \cdot \text { channel }_{i, t}+\theta \cdot X_{i, t}+\tau_{t}+\mu_{i}+\epsilon_{i, t}
$$

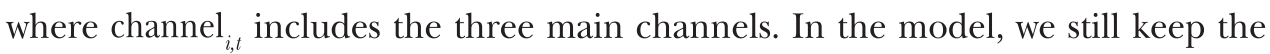
financial openness measure as an explanatory variable since financial openness may influence output volatility through channels other than capital flows volatility, real interest rate volatility, and crisis. In other words, the coefficient of financial openness represents the impact of financial openness on output volatility which is not captured explicitly by any of the three main channels. For the sake of robustness,

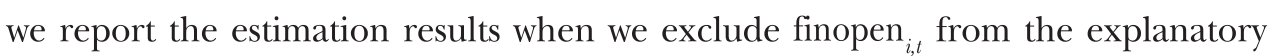
variables later in $<$ Table $8>$.

The results of our testing for the three main channels are reported in $<$ Table $4>$ to $<$ Table $7>$. $<$ Table $4>$ reports the results of our empirical analysis of the impact of

7) See, for example, Rodrik (1998), and Bhagwati (1998).

8) There is some scope for causality issues in the relationship between financial openness and crisis. For example, the IMF imposed capital account liberalization subsequent to a crisis in a limited number of cases. 
capital flow volatility on output volatility. We include the standard deviation of the ratio of net capital inflows to GDP as an additional explanatory variable. If we use the standard deviation of real GDP growth rates for each decade as a dependent variable, financial openness is highly significant in both de jure and de facto cases. This is true only for the entire sample and developing countries. After controlling for financial openness, volatile capital flows is not statistically significant in explaining the standard deviation of output growth in developing countries. Other control variables continue to be significant. These findings suggest that financial openness influences output volatility, but not through volatile capital flows. We also add an interaction term consisting of financial openness and capital flow volatility. The interaction term is not significant, suggesting that the extent to which financial openness increases output volatility does not depend on the degree of capital flow volatility.

However, if we experiment with an alternative measure of output volatility - the skewness of real GDP growth rates for each decade - the evidence is slightly different. After controlling for financial openness, we find some evidence that capital flow volatility makes output growth more negatively skewed, in column 1 of (b), but this is true only for the entire sample. There is no such evidence for developing countries.

$<$ Table $5>$ reports the results of our empirical analysis of the impact of real interest volatility on output volatility. We use the standard deviation of real interest rates as an additional explanatory variable. After controlling for financial openness, real interest rate volatility is not statistically significant in explaining the standard deviation or skewness of output growth rates in the entire sample or developing countries. However, there is some limited evidence that more volatile real interest rates are associated with higher standard deviation of output growth rates in advanced countries. When we use the de jure measure, the interaction term is statistically significant with a positive sign for developing countries - column 6 in (a). This finding suggests that more volatile interest rates may magnify the impact of financial openness on output volatility for developing countries. 


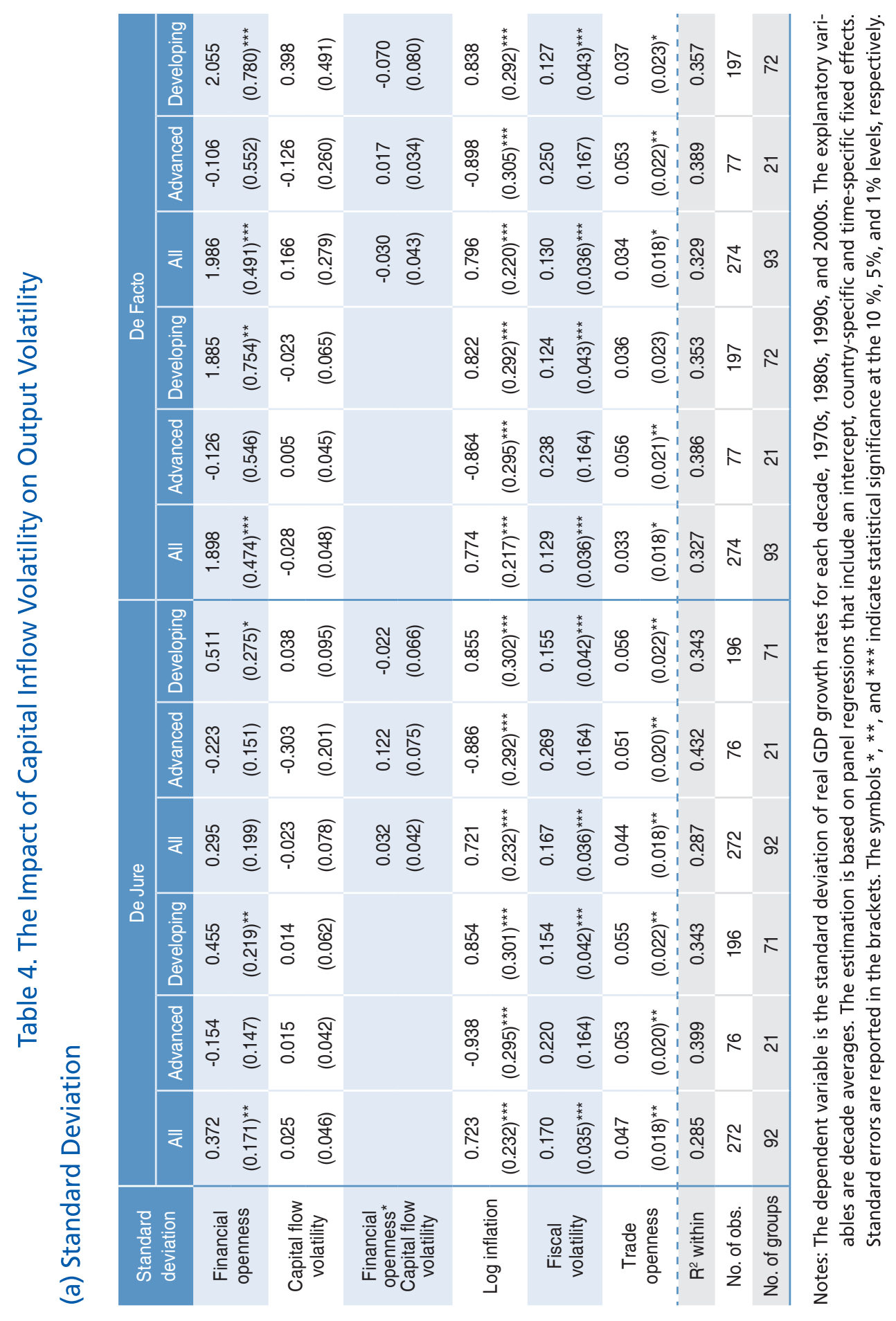




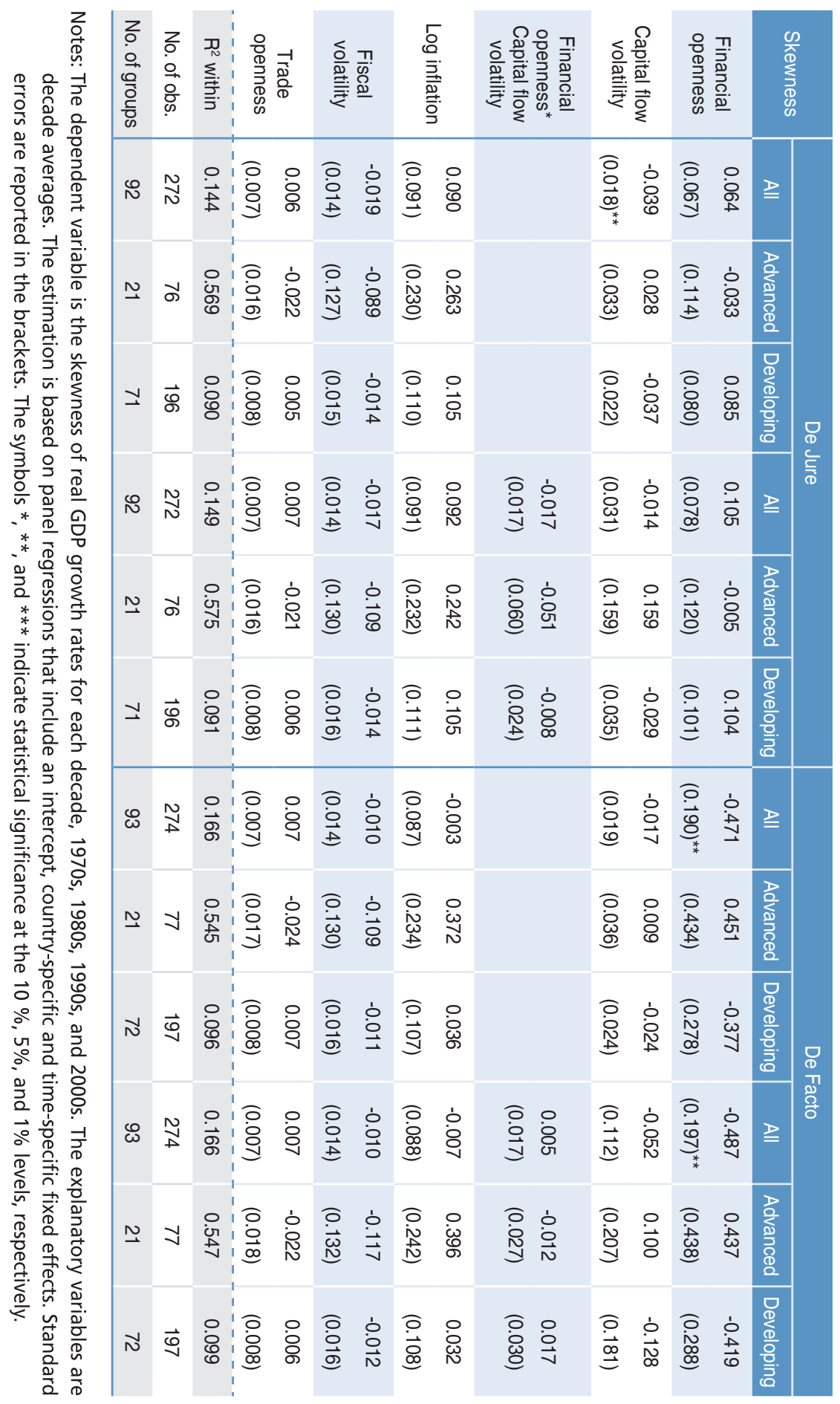




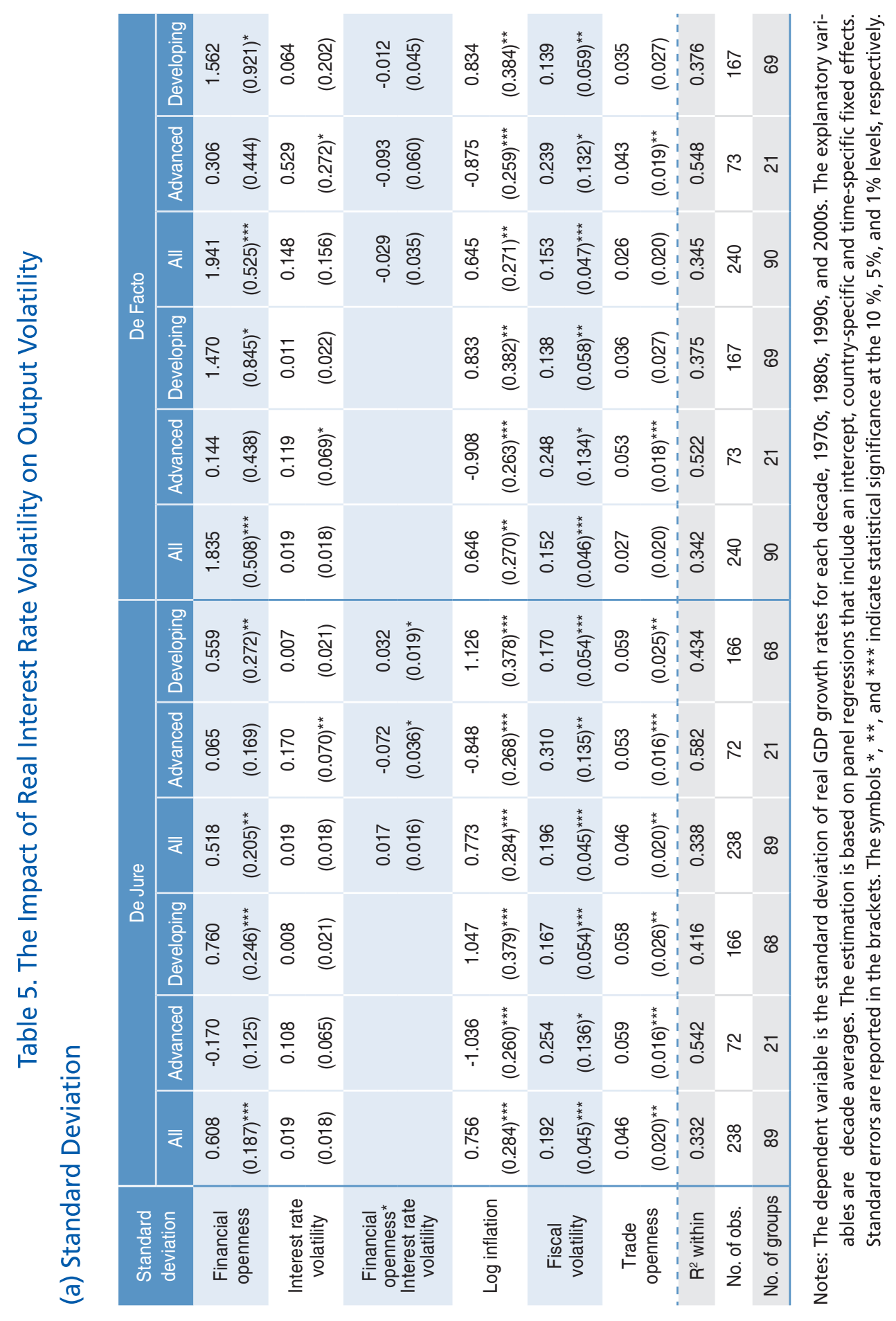




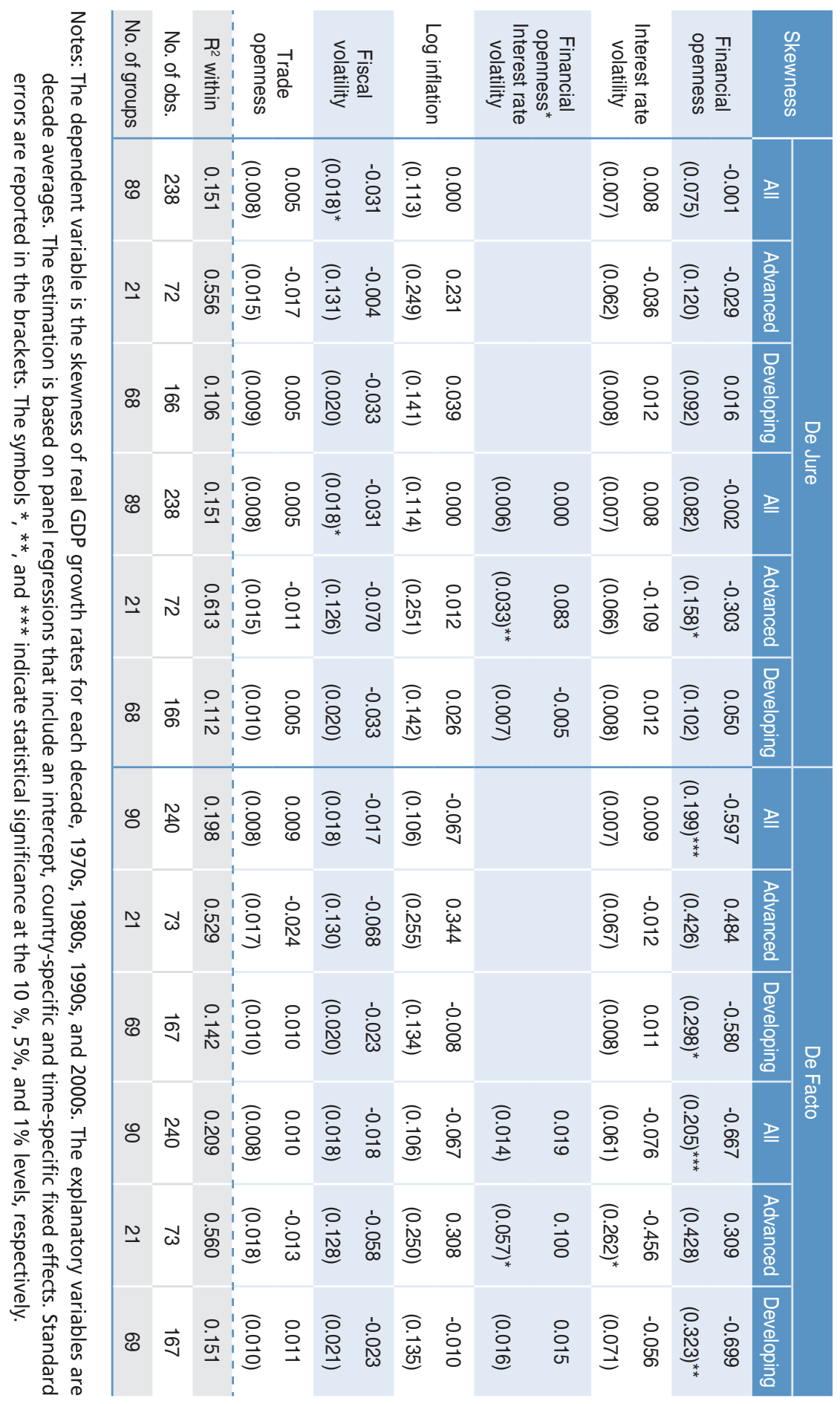


$<$ Table $6>$ reports the results of our empirical analysis of the impact of crisis on output volatility. A year dummy for crisis takes the value of one if a country experiences, in that particular year, either a currency crisis or an external debt crisis, as identified by Reinhart and Rogoff (2009). We then calculate its decade average to construct a crisis variable which is used as an explanatory variable. In many cases, the coefficients of the crisis variable are highly significant in explaining skewness as well as standard deviation of output growth rates. Interestingly, the coefficient of financial openness is no longer significant once the crisis variable is included, especially when we use the de jure financial openness measure. When we use the de facto measure, the coefficients of both financial openness and crisis are statistically significant in many cases, suggesting that financial openness affects output volatility through other channels as well as through the crisis channel. Overall, our evidence indicates that crisis is the main channel through which output volatility increases in financially open developing countries.

$<$ Table $7>$ reports the results of our analysis when we simultaneously include capital flow volatility, real interest rate volatility, and the crisis variable. We find that only the crisis variable is significant. The results are generally highly consistent with $<$ Table $6>$. 


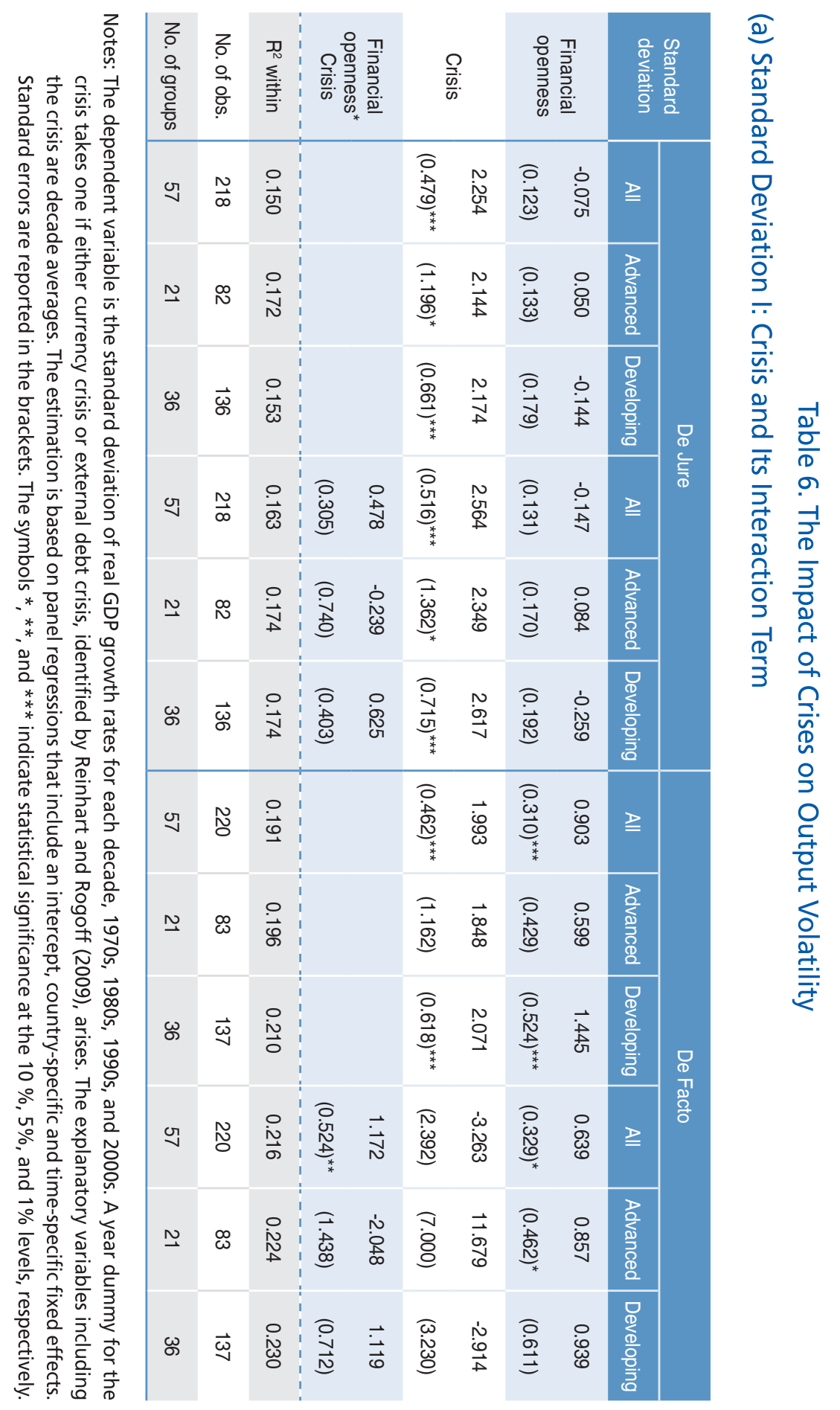




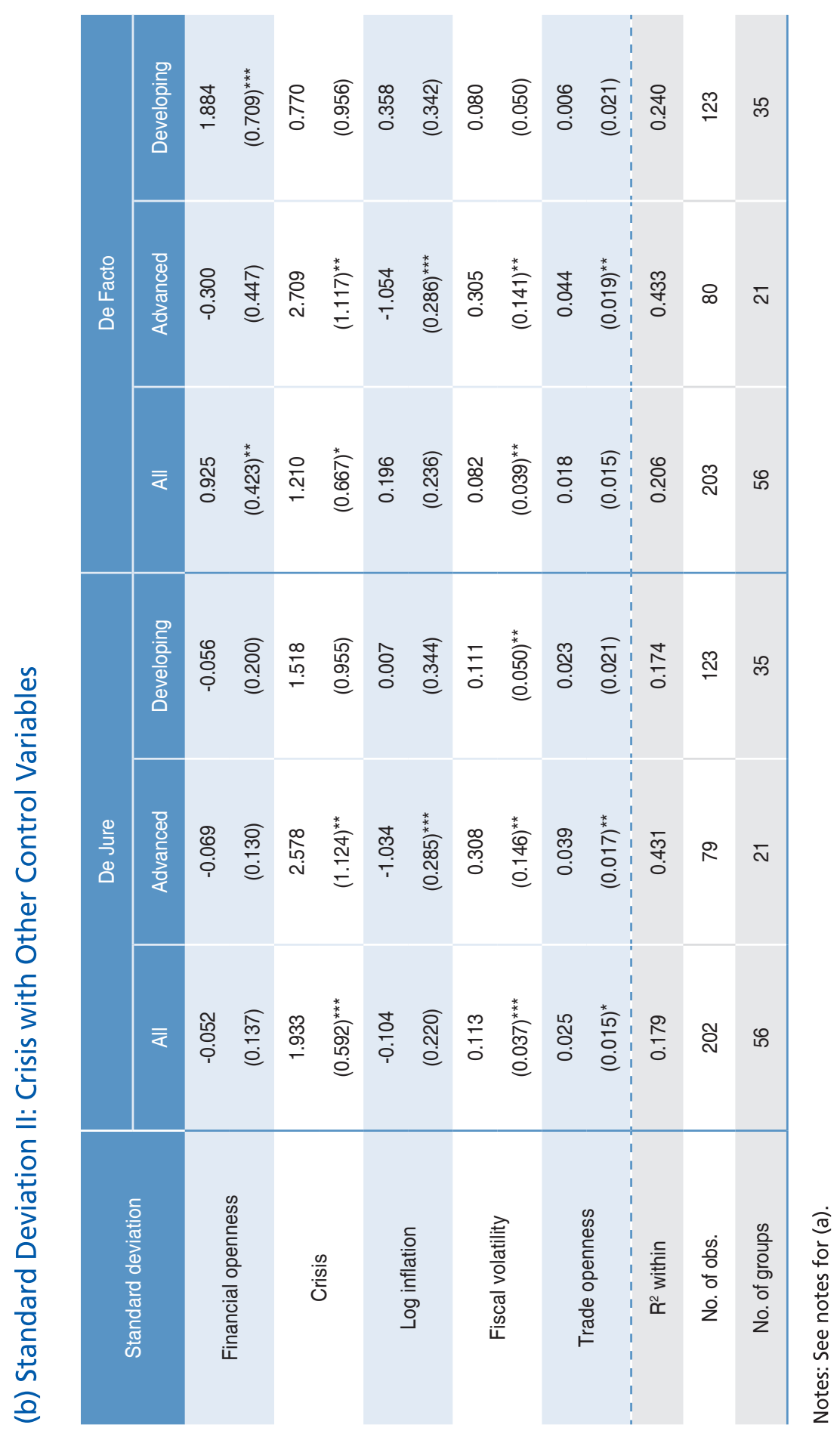




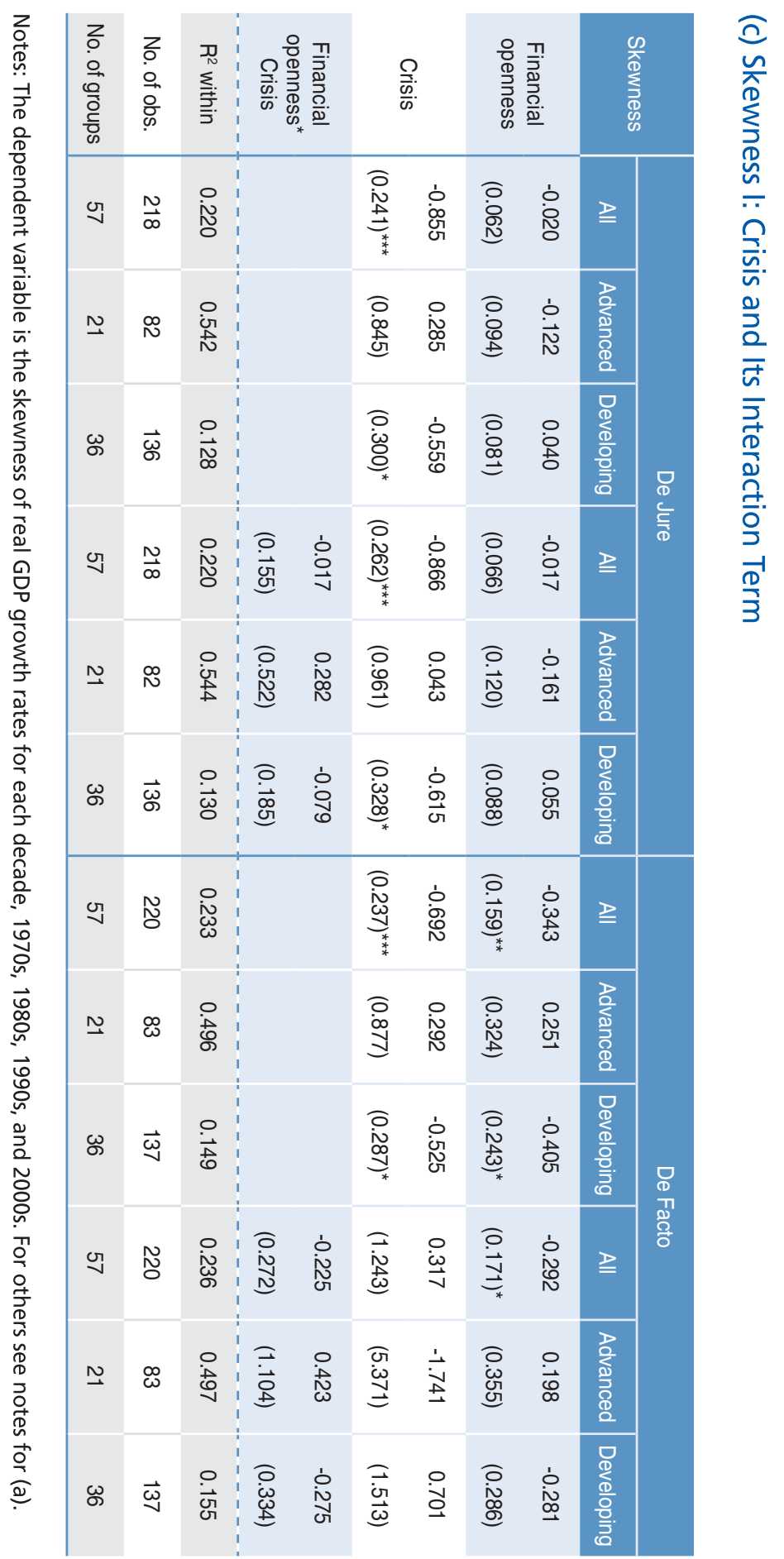




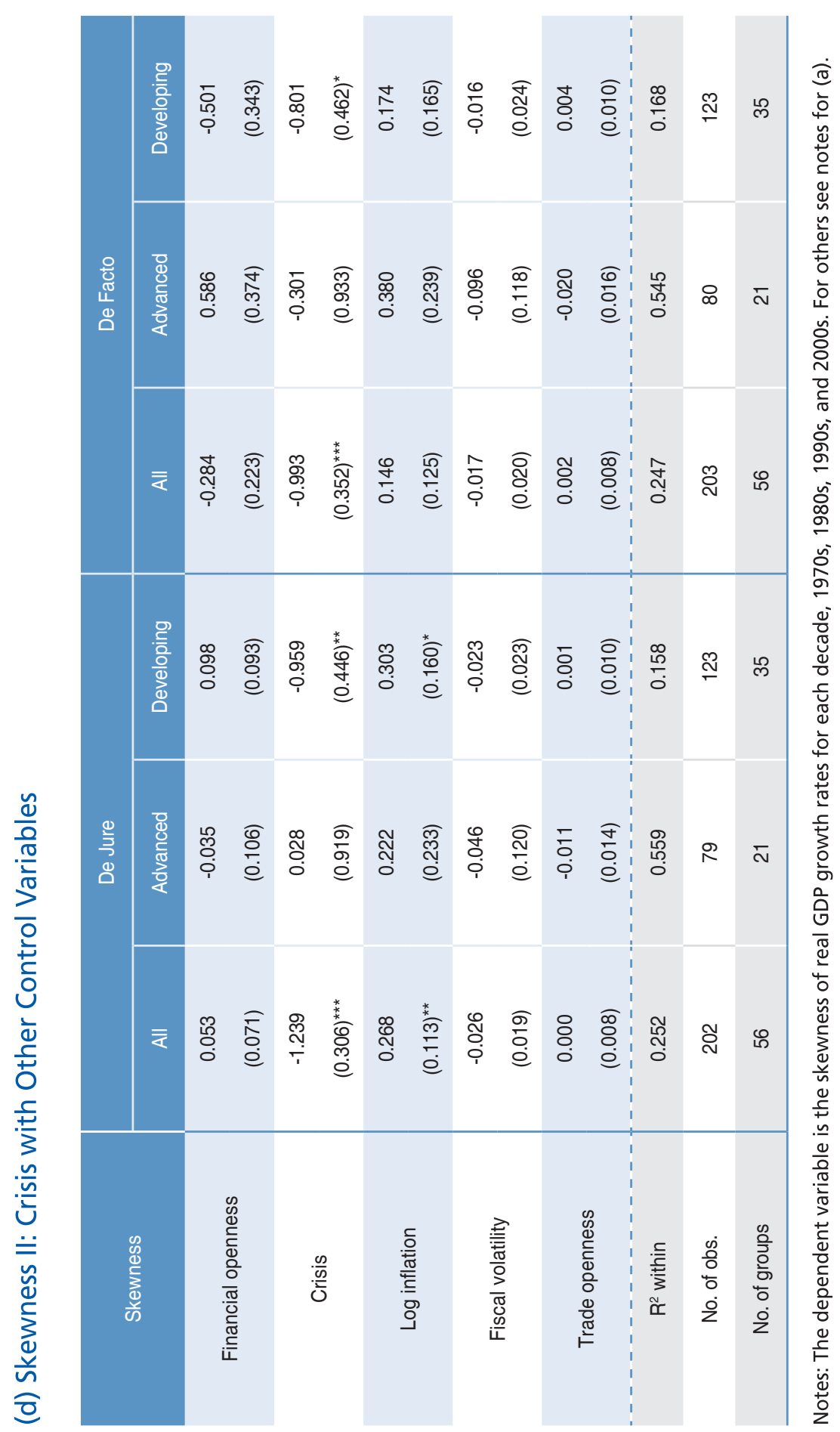




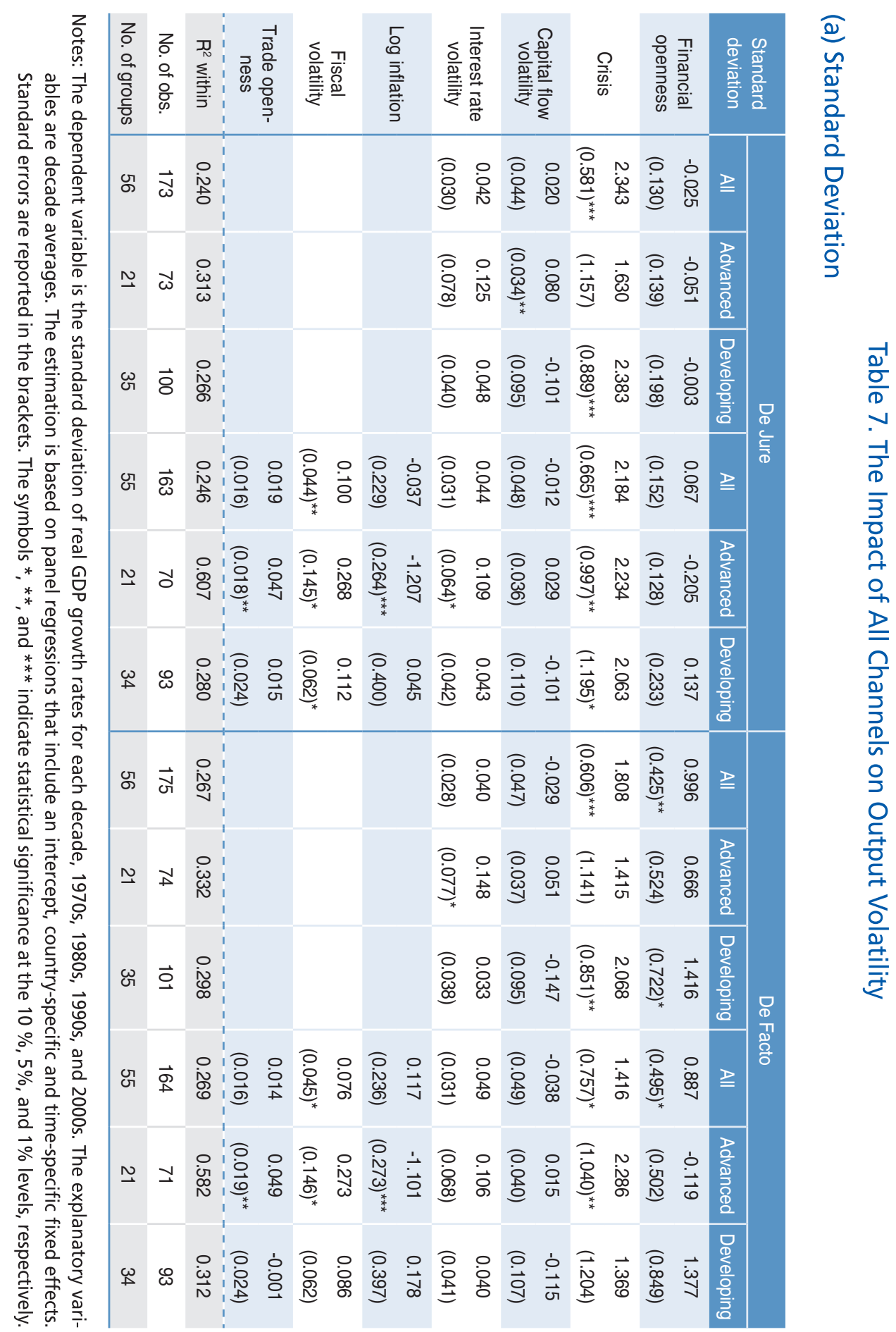




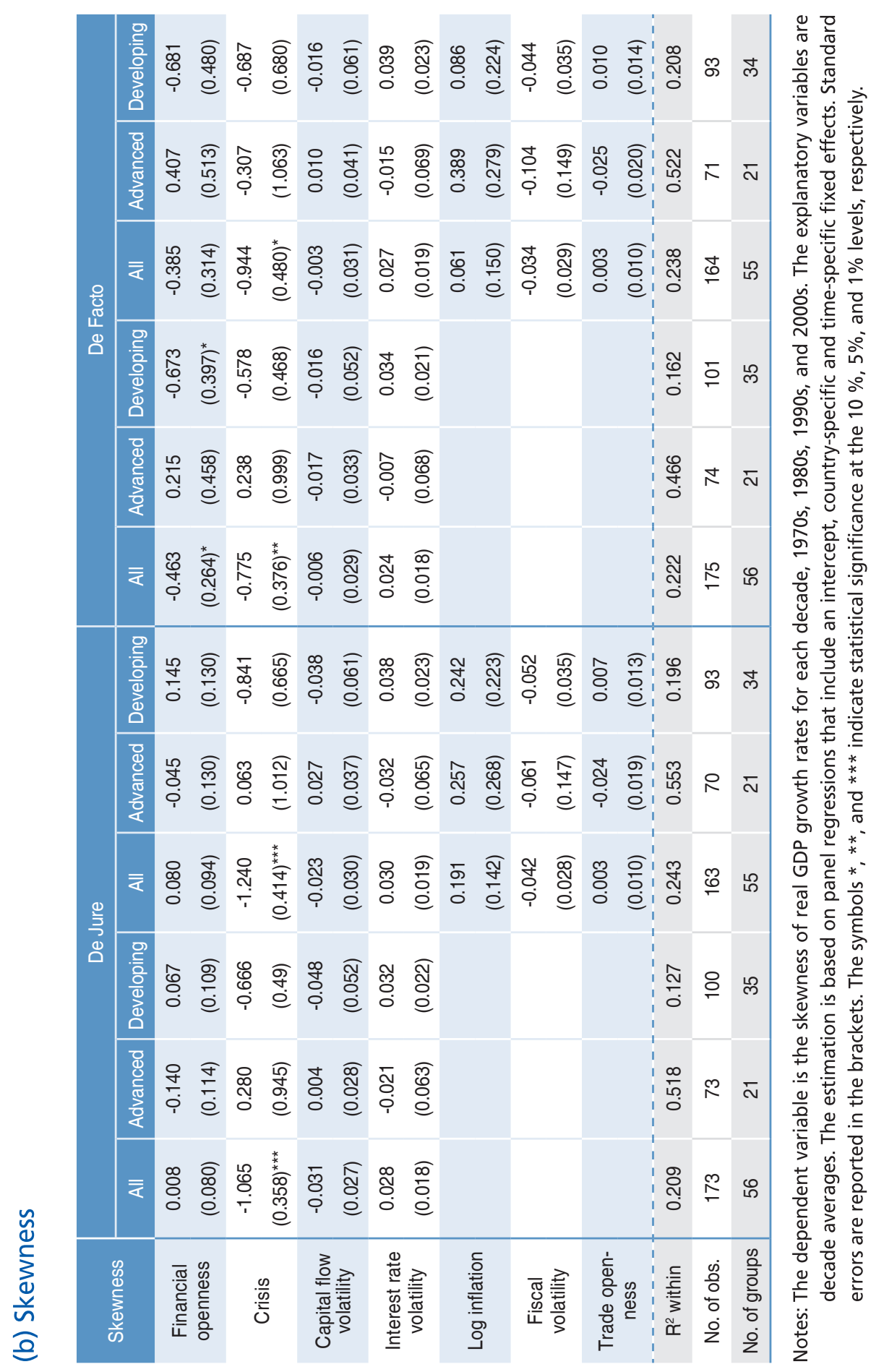


As a robustness check, we also consider the case in which financial openness affects output volatility only through the three main channels, but not through any other channel. For this purpose, we no longer include the financial openness measure as an explanatory variable. The results in $<$ Table $8>$ generally support our previous results. When the dependent variable is the standard deviation of output and only the three main channels are included as regressors ( $1^{\text {st }}$ to $3^{\text {rd }}$ columns), we find that only the crisis channel is statistically significant at the $1 \%$ level for the entire sample and for developing countries. For advanced countries, the coefficient of the crisis variable is positive but not statistically significant. In contrast, the coefficient of capital flow volatility is positive and statistically significant at the $1 \%$ level for advanced countries. If we include other control variables as regressors $\left(4^{\text {th }}\right.$ to $6^{\text {th }}$ columns), the coefficient of the crisis variable is positive and still significant at the $1 \%$ level for the entire sample. Interestingly, however, when we divide the sample into advanced and developing countries, the coefficient of the crisis variable is significant at the $5 \%$ level only for advanced countries. The coefficient of the crisis variable for developing countries is not statistically significant at conventional levels, but the p-value is quite low, less than .15 .

If we use skewness as the dependent variable, the results are generally consistent with the results for standard deviation. Regardless of whether the other control variables are excluded ( $7^{\text {th }}-9^{\text {th }}$ columns $)$ or included $\left(10^{\text {th }}-12^{\text {th }}\right.$ columns $)$, the coefficient of the crisis variable is negative and statistically significant at the $1 \%$ level for the entire sample. When we divide the sample into advanced and developing countries, the coefficient of the crisis variable is not significant for either group, but the pvalue is much lower for developing countries than for advanced countries. 


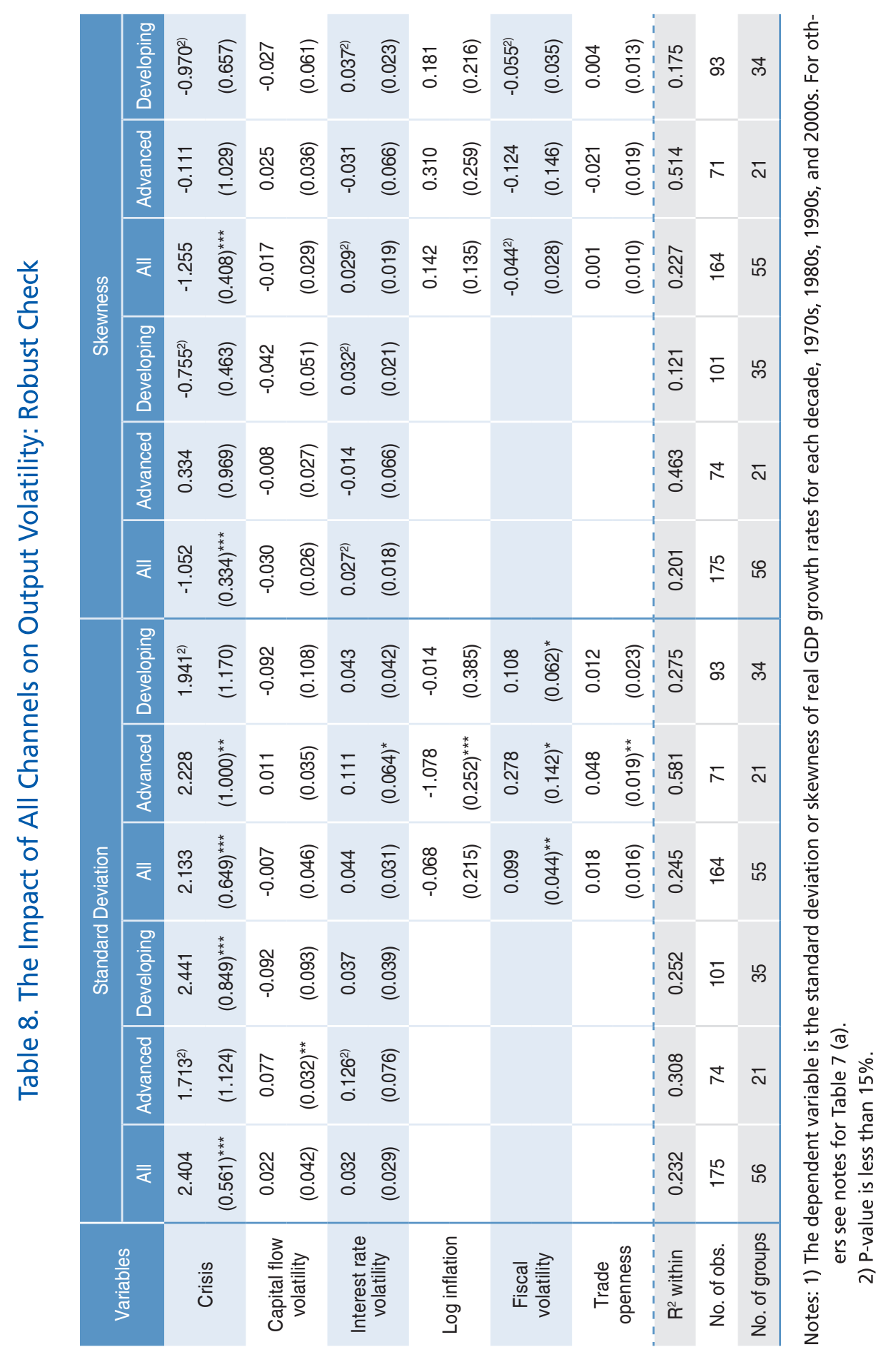


So far our evidence indicates that financial openness affects output volatility indirectly through crisis. However, we have not yet shown any evidence that financial openness actually increased the likelihood of crisis. In order to more accurately assess the relationship between financial openness and the crisis channel, we estimate the effect of financial openness on the probability of crisis in developing countries. We use a similar model as in our previous analyses, but employ a different estimation method. We use the decade average of the crisis dummy as the dependent variable. Since this takes a value between 0 and 1 , we perform random effect tobit estimations with lower bound 0 and upper bound 1 , with country and time specific fixed effects included.

In addition to financial openness measures, we add a number of additional explanatory variables that are expected to influence the likelihood of crisis. These include the ratio of short-term debt to total debt, the ratio of total debt to GDP, the ratio of current account balance to GDP, and the ratio of private domestic credit to GDP. However, the values of the explanatory variables are likely to differ a lot before and after crisis, which raises an endogeneous issue. We try two methods to address endogeneity. One method is to take the value of the pre-crisis year for the four new explanatory variables and take an average if there was a crisis. The other method is to just use average values of the previous decade. We also add the three control variables which we used in our previous regressions in both cases.

$<$ Table $9>$ reports the results of our in-depth analyses of the crisis channel. Columns (1) to (6) show the results using the first method, and the columns (7) to (12) show the results from the second method. We find that the probability of crisis in developing countries increases if the degree of de facto financial openness increases, which reinforces our finding that financial openness increases the volatility of output through the crisis channel. The increase in total debt ratio, especially the short-term debt ratio, is also highly related to the probability of crisis. However, we could not find any evidence of a relationship between de jure financial openness and crisis. Perhaps de jure financial openness precipitates financial sector reforms, and hence it does not necessarily increases the likelihood of crisis. 


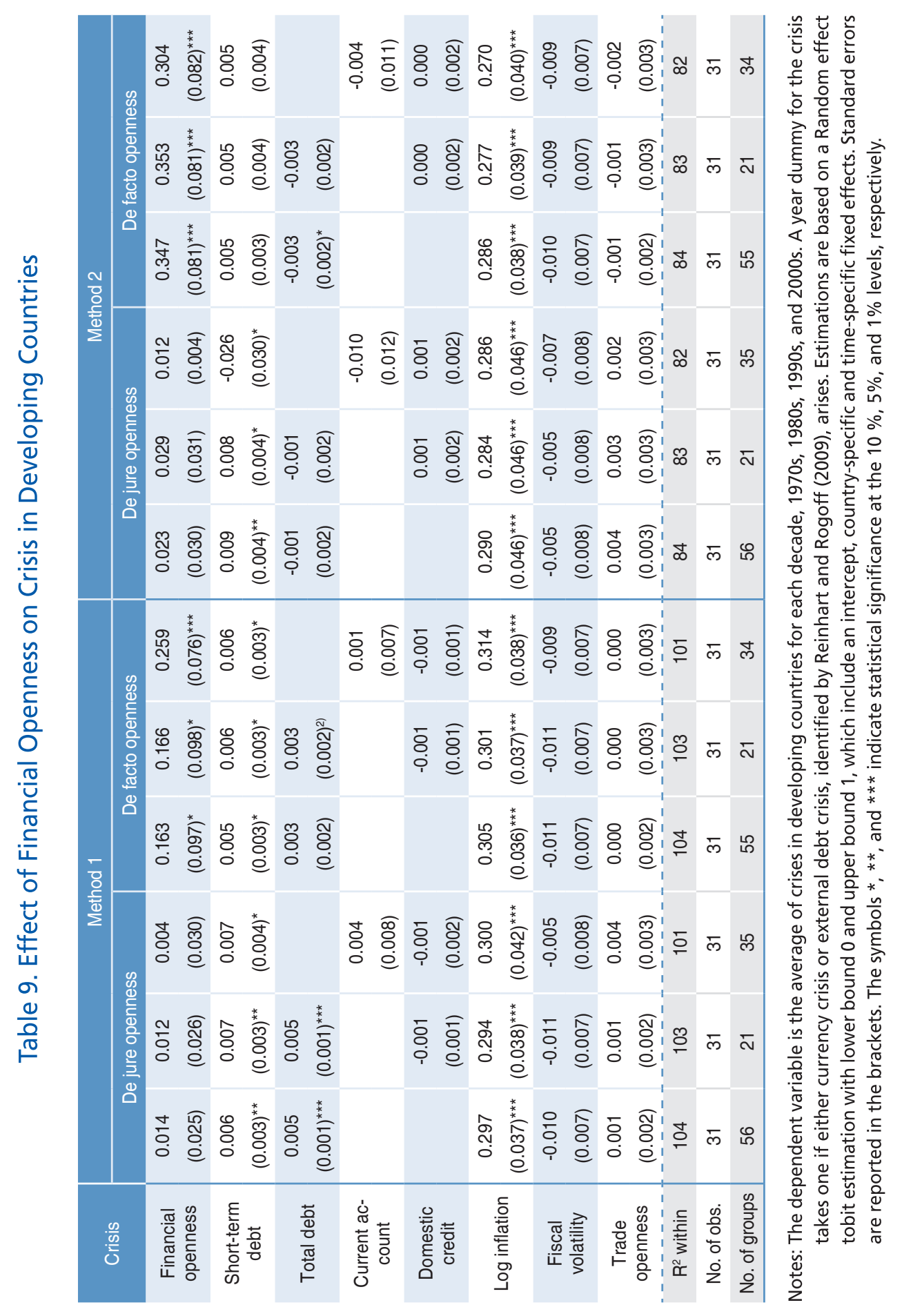




\section{Implication for Asian countries}

Capital inflows and their effects are emerging as major issues of interest for Asian policymakers in the aftermath of the global crisis. <Table 10> shows the summary statistics of Asian developing countries, and compares them with those of other developing countries. The average growth rate of Asian countries is higher than that of other developing countries. The standard deviation of output in Asian countries is lower than that of other countries except during the 1990s when some Asian countries suffered a currency crisis. On the other hand, the skewness of output is more negatively skewed in Asian countries, which implies greater output volatility. On average, Asian developing countries are financially more open than other developing countries, but the gaps narrowed after 2000 when other developing countries opened up their financial markets. We can also see that on average Asian countries are more open to trade than other countries, and are less prone to crisis.

Now we investigate if the impact of financial openness on output volatility is stronger in Asian countries. Since the crisis is the most significant channel through which financial openness influences output volatility, we look primarily at the crisis channel. $<$ Table $11>$ shows that output in the Asian economy becomes more volatile when it experiences a crisis. The interaction terms between the crisis dummy and the Asia region dummy are positive and statistically significant when the standard deviation of output is used as the dependent variable, and negative and statistically significant when the skewness of output is used as the dependent variable. This implies that crises have stronger impacts on output volatility in Asian countries.

However, we could not find any evidence that financial openness increases the probability of crisis to a greater extent in Asia than in other countries. <Table 12> shows that the interaction terms between financial openness measures and the Asia region dummy are negative, and highly significant. This implies that a crisis is less likely to occur in Asian countries when they open up their financial markets. Therefore, we can conclude that while financially open Asian countries are less likely to experience a crisis, once they suffer a crisis, their output becomes even more volatile than the output of other developing countries.

9) See, for example, Tille (2012) and Rime and Tranvag (2012). 


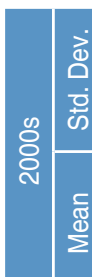

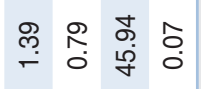$$
\text { 导莳 }
$$

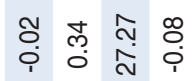

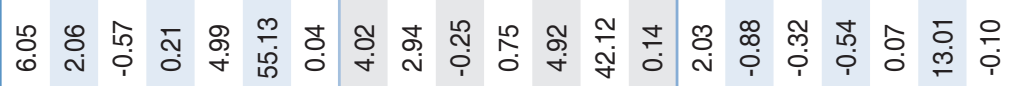

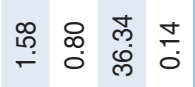

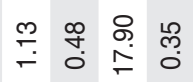

๘

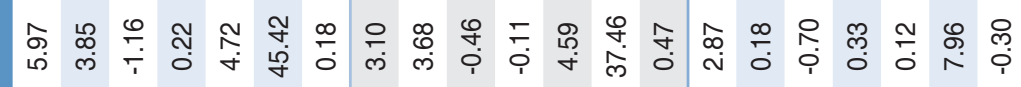

응 음

$\stackrel{\frac{1}{c}}{\frac{1}{0}}$

ร்

就 के के

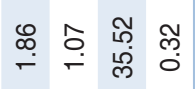

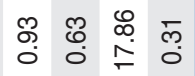

Љr

के

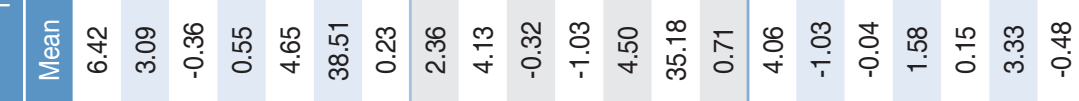

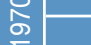

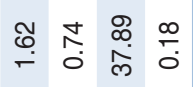

\begin{tabular}{llll}
$\infty$ & $\wp$ & $\hat{N}$ & $\mathbb{N}$ \\
\hdashline & 0 & $\stackrel{N}{*}$ & 0
\end{tabular}

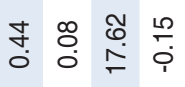

4

颃

营

$\frac{0}{\frac{0}{0}}$

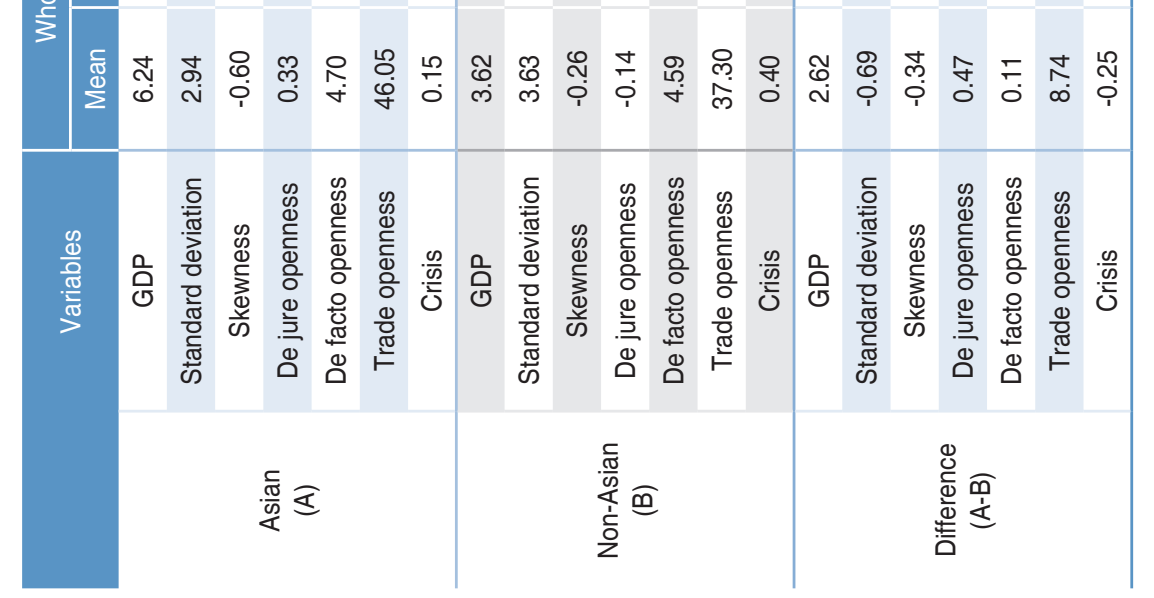

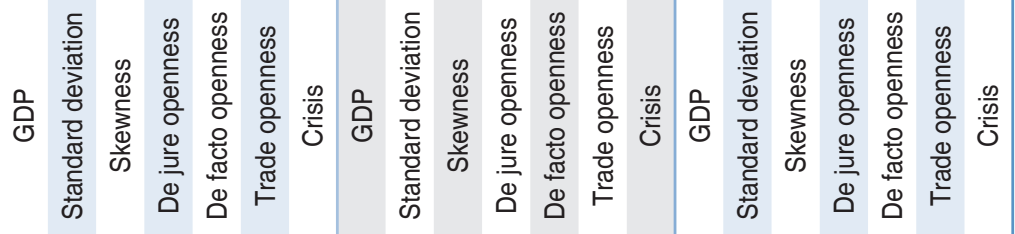

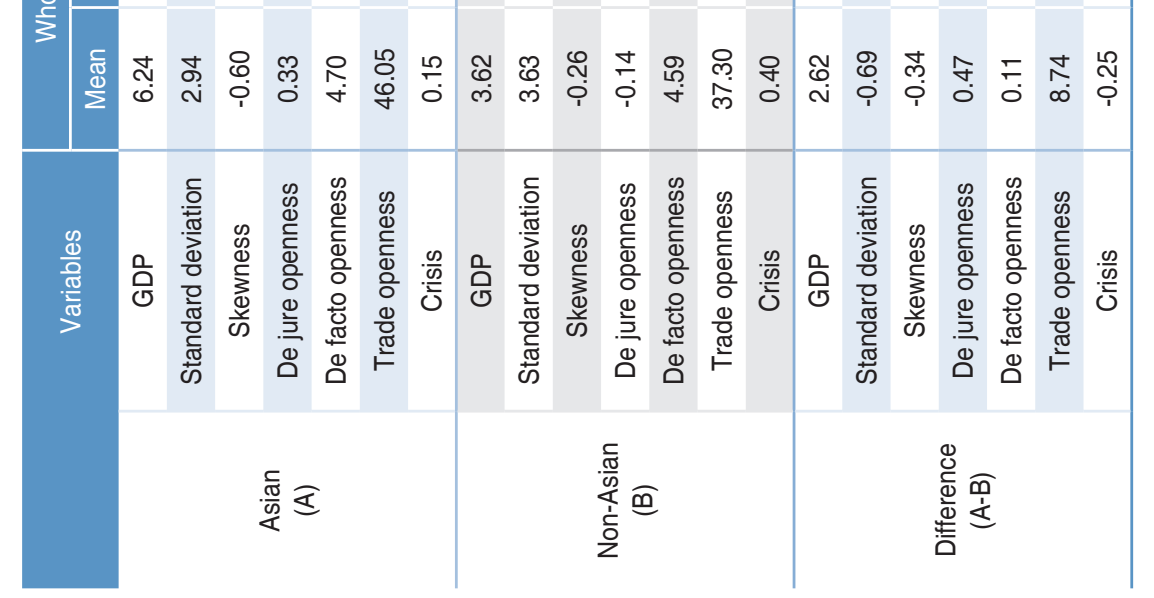

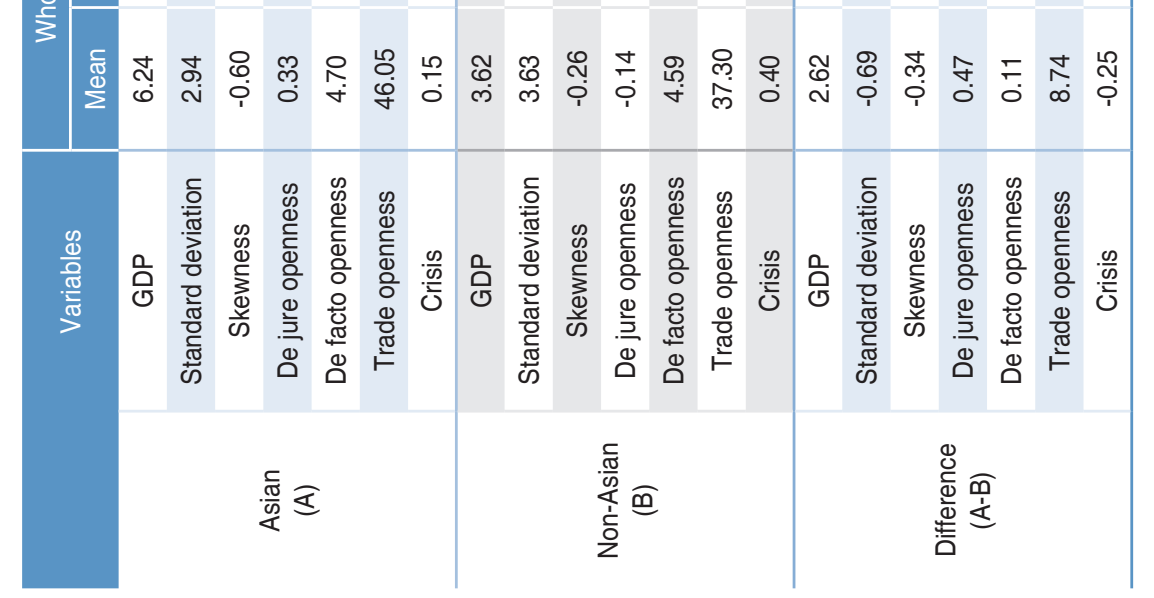

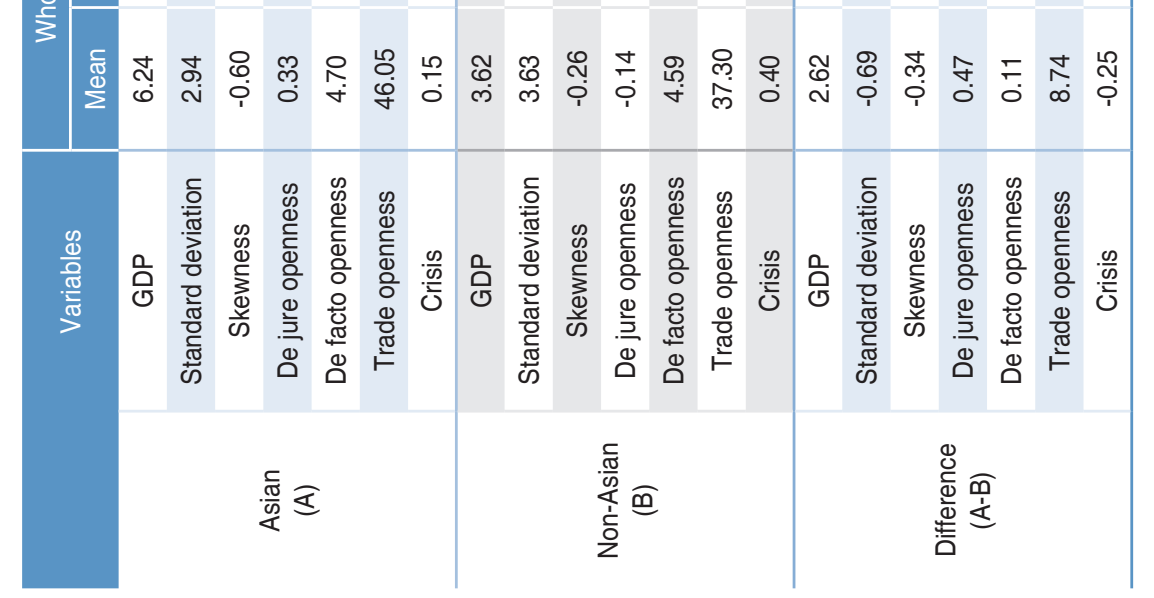

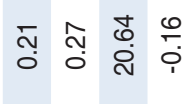

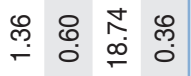

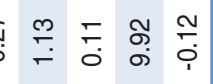

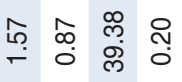

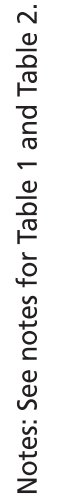




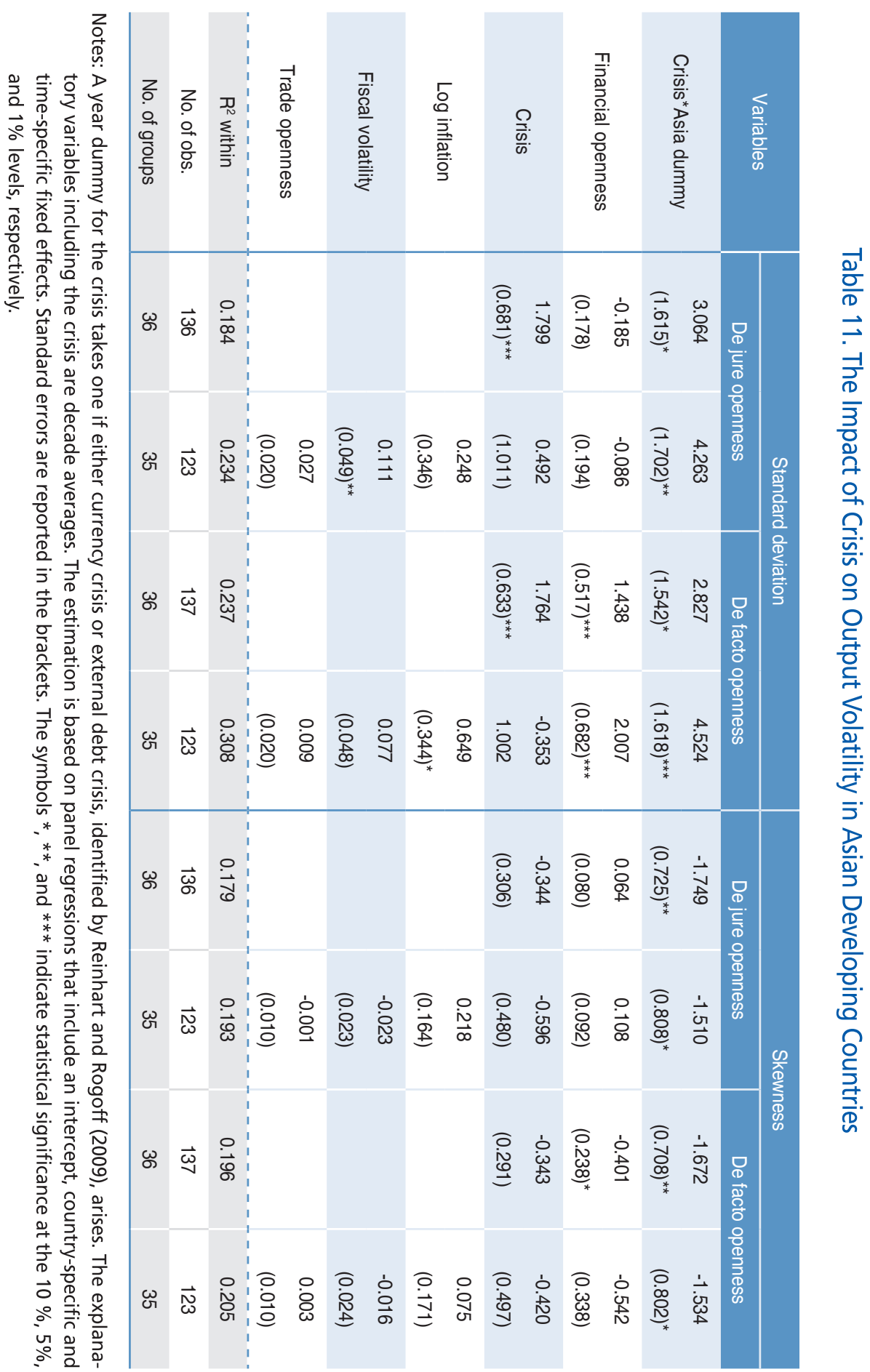




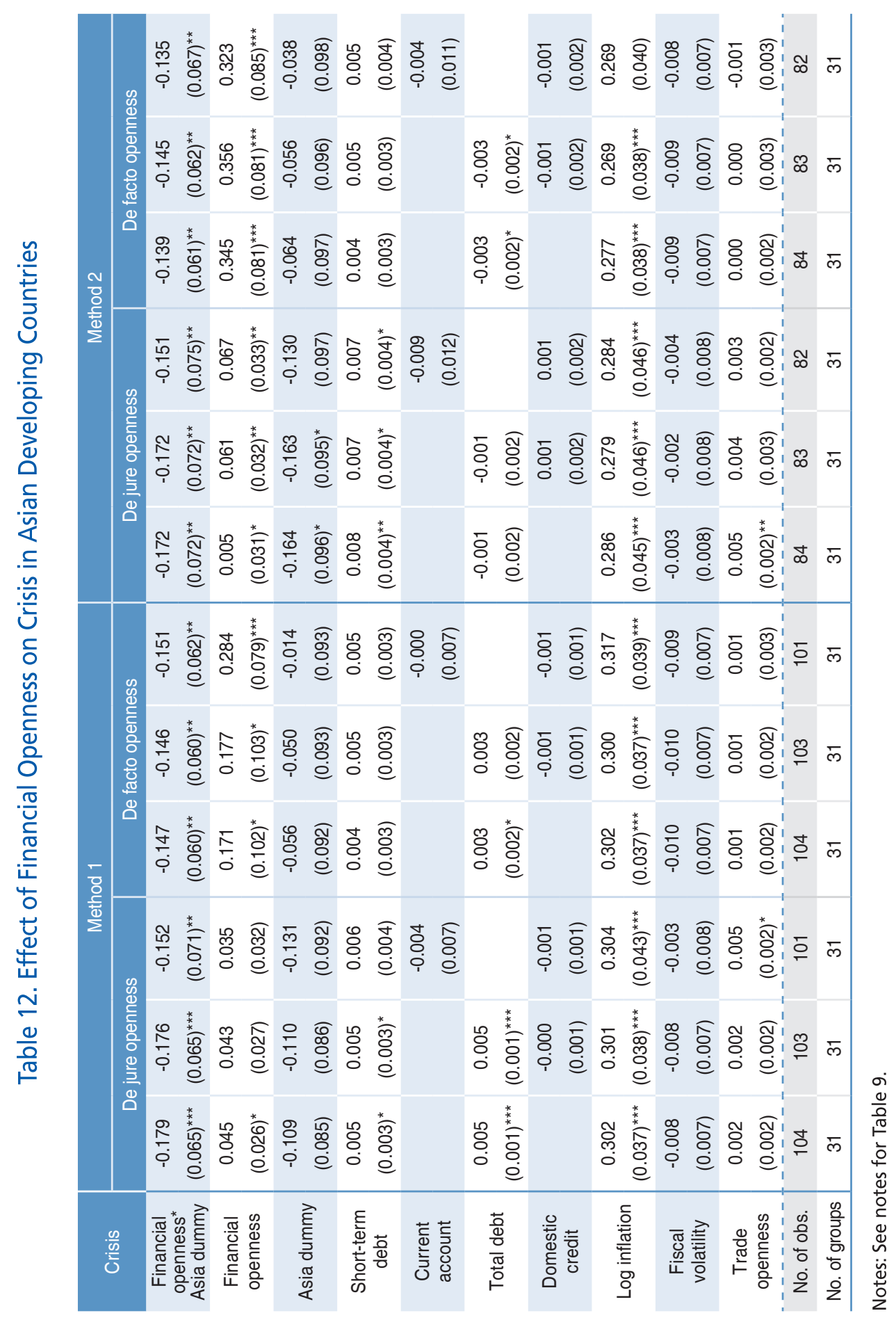




\section{Concluding Observations}

Financial openness is a highly controversial issue, especially in developing countries with underdeveloped financial systems. A widespread perception that financial openness is an externally imposed agenda originating from financially developed advanced economies further fuels the controversy. More generally, financial openness entails a number of benefits as well as costs. While the marginal returns to capital tend to be high in developing countries, their domestic savings can be insufficient to finance domestic investment. Financial openness enables such countries to access foreign savings and thus bridge the gap between domestic savings and investment. In fact, many developing countries were able to leverage foreign capital to power their growth. For an example, foreign direct investment made a substantial contribution to China's capital accumulation and technological upgrading. On the other hand, financial openness imposes a number of costs and risks. For an instance, it curtails monetary policy independence and thus the scope for using monetary policy for domestic objectives.

In this paper, we take a closer look at another major risk of financial openness i.e. output volatility. More specifically, we investigate the effect of financial openness on output volatility based on data from 81 developing and 21 advanced countries during 1971-2010. Concerns about financial openness in developing countries have largely centered on its potential for disrupting and destabilizing the financial system and real economy. Such concerns have intensified recently due to the global financial crisis. Our most significant finding is that financial openness increases output volatility in developing countries but not in advanced economies. This is plausible since advanced economies have more developed financial systems than developing countries.

Theoretically, capital flow volatility, interest rate volatility, and crisis are the main channels through which financial openness magnifies output volatility. However, we find that only the crisis channel is statistically significant. Furthermore, our findings suggest that the channel is only in effect for developing countries. This is also plausible since financial openness has contributed to financial and economic crises mostly in developing countries. Interestingly we find some differences between Asian developing countries and other developing countries. In particular, financial openness 
is less likely to cause a crisis in Asian countries, but once they suffer a crisis, their output becomes even more volatile than the output of other developing countries.

Our results have a number of policy implications. Above all, the significant effect of financial openness on output volatility in developing countries strengthens the case for caution in opening up to cross-border capital flows. In recent years, there has been a growing recognition that financial openness can destabilize financially underdeveloped developing countries. Reflecting this trend, even the IMF, which used to oppose restrictions on capital flows as a matter of principle, has become more tolerant toward such restrictions. While our findings pertain to only one specific effect of financial openness on output volatility, they nevertheless support a need to open up capital markets in a cautious and gradual manner. All the more so since developing countries have experienced greater output volatility after the global financial crisis. ${ }^{10)}$

In addition, financial development will weaken the link between financial openness and crisis. However, financial development is necessarily a long term process. In the meantime, measures such as stronger prudential supervision and regulation will be needed to weaken the link in the short and medium term.

10) In this connection, the heightened uncertainty surrounding the global outlook since the global financial crisis is of particular concern. For example, Lam and Yetman (forthcoming) find it highly unlikely that the Asia-Pacific region will decouple from the rest of the global economy anytime soon. 


\section{References}

Anwar, Sajid, 2008, "Foreign Investment, Human Capital and Manufacturing Sector Growth in Singapore," Journal of Policy Modeling, Vol. 30(3), pp. 447-453.

Barrell, Ray, and Sylvia Gottschalk, 2004, "The Volatility Of The Output Gap In The G7,” Royal Economic Society Annual Conference 2004, Royal Economic Society.

Bekaert, Geert, Campbell R. Harvey, and Christian Lundblad, 2006, "Growth volatility and equity market liberalization," Journal of International Money and Finance, Elsevier, Vol. 25(3), pp. 370-403.

Bonfiglioli, Alessandra, and Caterina Mendicino, 2004, "Financial Liberalization, Banking Crises, and Growth: Assessing the Links," Working Paper Series, Stockholm School of Economics.

Buch, Claudia M., Joerg Doepke, and Christian Pierdzioch, 2005, "Financial openness and business cycle volatility," Journal of International Money and Finance, Elsevier, Vol. 24(5), pp. 744-765.

Chinn, Menzie, and Hiro Ito, 2006, "What Matters for Financial Development? Capital Controls, Institutions and Interactions," Journal of Development Economics, Vol. 81(1).

Edison, Hali, Ross Levine, Luca Ricci, and Torsten Sløk, 2002, "International Financial Integration and Economic Growth," Journal of International Monetary and Finance, Vol. 21(6).

Edwards, Sebastian, 2008, "Financial Openness, Currency Crises and Output Losses," in Financial Markets Volatility and Performance in Emerging Markets, ed. by Sebastian Edwards and Márcio G. P. Garcia, University of Chicago Press.

Feridun, Mete, and Yaya Sissoko, 2011, "Impact of FDI on Economic Development: A Causality Analysis for Singapore, 1976-2002," International Journal of Economic Sciences and Applied Research, Vol. 4(1).

Frankel, Jeffrey, 1992, "Measuring International Capital Mobility: A Review," American Economic Review, Vol. 82. 
Giovanni, Julian di, and Andrei A. Levchenko, 2006, "Trade Openness and Volatility," Development Working Papers 219, Centro Studi Luca d`'Agliano, University of Milano.

Glick, Reuven, Xueyan Guo, and Michael Hutchison, 2006, "Currency Crises, Capital Account Liberalization, and Selection Bias," Review of Economics and Statistics. Vol 88(4).

Grilli, Vittorio, and Gian Maria Milesi-Ferretti, 1995, "Economic Effects and Structural Determinants of Capital Controls," IMF Staff Papers, Vol. 42(3).

Jayawickrama, Ananda, and Shandre M. Thangavelu, 2010, "FDI Activities, Exports and Manufacturing Growth in a Small Open Economy: An Industry-wise Panel Data Analysis," paper presented at the Fourth Joint Economics Symposium of Five Leading East Asian Universities, Hong Kong.

Klein, Michael, and Giovanni Olivei, 2006, "Capital Account Liberalization, Financial Depth, and Economic Growth,” Working Paper, Tufts University.

Kose, M. A., E. S. Prasad, and M. E. Terrones, 2003, "Financial integration and macroeconomic volatility," IMF Staff Papers 50, pp.119-142.

Kose, M. A., E. S. Prasad, and M. E. Terrones, 2006, "How Do Trade and Financial Integration Affect the Relationship Between Growth and Volatility?," Journal of International Economics 69, pp. 176-202.

Kose, Ayhan, Eswar Prasad, Kenneth Rogoff, and Shang-Jin Wei, 2009, "Financial globalization: A reappraisal," IMF Staff Papers, Vol. 56(1), pp. 8-62.

Lam, L. and J. Yetman (forthcoming), "Asia's decoupling: fact, fairytale or forecast?" Pacific Economic Review.

Lane, Philip R., 2006, "The External Wealth of Nations Mark II: Revised and Extended Estimates of Foreign Assets and Liabilities, 1970-2004," IMF Working Paper 06/69.

Lane, Philip R., and Gian Maria Milesi-Ferretti, 2007, "Europe and Global Imbalances," Economic Policy 22, pp. 519-573. 
Levchenko, Andrei A., Romain Rancière, and Mathias Thoenig, 2009, "Growth and risk at the industry level: The real effects of financial liberalization," Journal of Development Economics, Vol. 89(2), pp. 210-222.

Loayza, Norman V., Romain Ranciere, Luis Serven, and Jaume Ventura, 2007, "Macroeconomic Volatility and Welfare in Developing Countries: An Introduction," World Bank Economic Review, 21 (3), pp. 343-357.

Meller, Barbara, 2008, "Output volatility in the era of financial globalization," Working Paper, Goethe University.

Mendoza, Enrique, 2006, "Lessons from the Debt Deflation Theory of Sudden Stops," American Economic Review, Vol. 96(2).

Neumeyer, Pablo A., and Fabrizio Perri, 2005, "Business Cycles in Emerging Economies: the Role of Interest Rates," Journal of Monetary Economics, Vol. 52(2).

Popov, Alexander, 2011, "Output Growth and Fluctuations: the Role of Financial Openness," Working Paper Series 1368, European Central Bank.

Prasad, Eswar S., Kenneth Rogoff, Shang-Jin Wei, and M. A. Kose, 2007, "Financial Globalization, Growth and Volatility in Developing Countries," NBER Chapters, in: Globalization and Poverty, National Bureau of Economic Research, pp. $457-516$.

Quinn, Dennis, 2003, “Capital Account Liberalization and Financial Globalization, 1890-1999: A Synoptic View," International Journal of Finance and Economics, Vol. 8(3).

Razin, Assaf, and Andrew K. Rose, 1994, "Business-cycle volatility and openness: An exploratory cross-sectional analysis. In Capital mobility: The impact on consumption, investment, and growth," ed. Leonardo Leiderman and Assaf Razin, Cambridge: Cambridge University Press, pp. 48-76.

Reinhart, C., and K. Rogoff, 2009, “This time is different,” Princeton University Press.

Reinhart, C., and K. Rogoff, 2010, "From Financial Crash to Debt Crisis," NBER Working Paper No. 15795, National Bureau of Economic Research. 
Rime, D. and H.J. Tranvag, 2012, "The Flows of the Pacific: Asian Foreign Exchange Markets through Tranquillity and Turbulence," Pacific Economic Review, Vol. 17(3).

Rodrik, Dani, 1998, "Who Needs Capital-Account Convertibility?," Essays in International Finance, No. 207, Princeton University.

Spatafora, Nikola, and Martin Sommer, 2007, "The Changing Dynamics of the Global Business Cycle," Chapter 5 in World Economic Outlook: Globalization and Inequality.

Tille, Cedric, 2012, "Sailing through this Storm? Capital Flows in Asia during the Crisis," Pacific Economic Review, 17(3). 


\section{$<$ Abstract in Korean $>$}

\section{황광명*, 박동현**, 신관호}

자본시장 개방은 일반적으로 편익과 비용을 수반하게 되는데, 비용 측면에서 가장 중 요하게 거론되는 것은 경기 변동성의 확대이다. 본 논문에서는 21 개 선진국과 81 개 개도국의 1971 년부터 2010 년까지 자료를 이용하여 자본시장 개방이 경기변동성에 미치는 영향을 실증분석하였다. 분석결과 자본시장 개방은 개도국의 경기변동성을 유의하게 높이는 것으로 나타났다. 또한 자본시장 개방이 경기변동성을 높이는 주요 경로는 통화 및 대외부채 위기 발생 가능성 확대임을 확인하였다. 마지막으로 아시아 개도국의 경우 자본시장 개방에 따른 위기의 발생가능성은 낮지만, 일단 위기가 발생 하면 경기변동성에 미치는 영향이 다른 개도국에 비해 큰 것으로 나타났다. 상기 결 과는 개도국이 자본시장 개방을 추진함에 있어 경기변동성이 확대될 수 있음을 고려 하여 신중하고 점진적인 방식으로 추진해야 함을 시사한다.

* 한국은행 경제연구원 거시경제연구실 선임연구원

** ADB Economics and Research Department, Principal Economist

*** 고려대학교 경제학과 교수 
( 